\title{
CORPORATE GOVERNANCE AND CEO TURNOVER DECISIONS*
}

\author{
Theodosios Dimopoulos ${ }^{* *}$ \\ HEC Lausanne and Swiss Finance Institute \\ Hannes F. Wagner ${ }^{* * *}$ \\ Bocconi University
}

March 2016

* We thank Brian Cheffins, Julian Franks, Denis Gromb, Christopher Hennessy, Igor Makarov, Luc Renneboog, Vikrant Vig, Paolo Volpin, and seminar participants at the 6th CEFS-IGIER Symposium on Economics and Institutions on Capri (2010), the German Finance Association Conference in Hamburg (2010), the Symposium on International Corporate Finance and Governance in Twente (2010), Bocconi University and London Business School for useful comments and suggestions. We are grateful to Manifest Information Services Ltd., Xiaoyan Zhang, Ingolf Dittmann, Ernst Maug and Christoph Schneider for giving us access to some of the data used, and to Emilio Manfredi and Enrico Tolusso for excellent research support. We gratefully acknowledge research support from the ESRC (Grant No. R060230004) and the London Business School's Centre of Corporate Governance.

** Corresponding author, HEC Lausanne and Swiss Finance Institute, Université de Lausanne, Quartier UNIL-Dorigny Bâtiment Extranef, 237, 1015 Lausanne. Phone: +41-21-692-3398. Email: Theodosios. Dimopoulos@unil.ch. Web: www.hec.unil.ch/people/tdimopoulos.

*** Department of Finance, Bocconi University, Via Roentgen 1, 20136 Milan, Italy. Phone: +39-02-58363528. Email: hannes.wagner@unibocconi.it. Web: faculty.unibocconi.eu/hanneswagner. 


\title{
CORPORATE GOVERNANCE AND CEO TURNOVER DECISIONS
}

\begin{abstract}
This paper provides a cross-country analysis to determine whether CEO turnover is a credible disciplining device for managers, whether it is effective in delivering performance improvements, and whether better governance improves the credibility and effectiveness of CEO turnover. The analysis is based on a detailed panel of 5,300 CEO years and spans two distinctly different financial systems-the U.K. and Germany-over the period 1995-2005. We find that CEOs face a credible threat of being removed for underperformance and that the hiring of new CEOs is effective in realizing large profitability improvements in the following years. We also find both relations to be virtually identical in both countries, despite large structural governance differences. Further, we consider a large number of firm-specific governance mechanisms previously proposed as indicators of better governance and find no evidence that any of them improves the observed relations between firm performance and CEO turnover. Taken together, our results suggest that replacing the CEO is an important component of successful turnarounds in underperforming firms and that this economic mechanism appears to work in nearly identical ways across very different financial markets, and across firms with very different quality of governance.
\end{abstract}

\section{JEL Classifications: G30, G34}

Keywords: CEO, board, turnover, performance, restructuring 


\section{Introduction}

Corporate governance research is primarily concerned with mechanisms that align the interests of managers with those of shareholders. In that sense, governance mechanisms are aimed at ensuring a closer alignment of these interests. One of the main such mechanisms available to shareholders is the threat of replacing top management. To prevent performance declines, this threat needs to be credible: the likelihood that a CEO is replaced must increase as performance worsens. And, for CEO turnover to be effective, CEO replacement decisions need to yield performance improvements under the management of the new CEO. In this paper, we use a cross-country analysis to determine, first, whether CEO turnover is a credible threat and whether it is effective; and second, whether governance mechanisms influence the credibility and effectiveness of CEO turnover.

In the U.S., there is strong evidence that the turnover threat is credible, (e.g. Warner et al., 1988, Weisbach, 1988, Denis et al., 1997, Huson et al. 2001, and Jenter and Lewellen, 2010). There is also some evidence that CEO replacement decisions are effective in U.S. firms (e.g. Bonnier and Bruner, 1989, Denis and Denis, 1995, and Hotchkiss, 1995). There is only weak evidence, however, that governance mechanisms affect both relations simultaneously, except for the specific case of outsider-dominated boards (Weisbach, 1988, and Huson et al., 2004).

Outside the U.S., empirical research faces significant challenges. Typically, broad crosscountry studies of CEO turnover have short time series and lack important control variables, such as whether the CEO is monitored by an insider- or outsider dominated board, while single- 
country studies have to rely on small, often hand-collected samples. ${ }^{1}$ As CEO changes are relatively rare events, the importance of sample size is compounded. ${ }^{2}$ At the same time, it is crucial to understand the mechanisms of CEO turnover across financial systems, as shareholders everywhere face the need to align the interests of management with their own, and forced CEO turnover is one of the few governance mechanisms that are universally available.

The goal of our paper is to use a large number of CEO turnover events from two distinctly different financial systems - the U.K. and Germany - to answer whether the threat of CEO turnover is credible and effective across countries and to shed light on whether or not governance improves the credibility and effectiveness of this threat. In doing so we rely on detailed and carefully hand-cleaned board data and matched firm-level governance data, which allows us to get very close to the state of the art in current U.S. turnover samples. The obvious price we pay for insisting on detailed firm-level data is that data collection costs limit our sample to just two countries. Our paper is not the first to provide CEO turnover evidence outside the U.S. There is prior evidence that the CEO turnover threat is credible elsewhere, but few papers consider simultaneously the firing and hiring decision as we do, none use similarly large board data panels and at the same time detailed firm-level governance data, and none explicitly rule out mean reversion of firm performance as an alternative hypothesis. Our sample spans the decade of 1995-2005, and includes 5,300 CEO years and 812 CEO changes, for 723 U.K. and 309 German

\footnotetext{
${ }^{1}$ The first cross-country study of CEO turnover by Kaplan (1994a) uses a sample of 448 Japanese and 485 U.S. CEO-year observations. Global samples of CEO changes are used in Defond and Hung (2004) (3,179 firms), Gibson (2003) (1,204 firms) and Lel and Miller (2008) (19,091 firms), although the first two papers cover a time period of five years, which is shorter than the average tenure of a U.S. CEO of around six years. Significantly, none of these papers consider board characteristics, such as board size or number of outside directors, or CEO characteristics, such as age or whether the incoming CEO is an insider or outsider. In single-country studies, CEO turnover is analyzed for Germany in Kaplan (1994b) using 42 firms; in Koeke (2004), using 664 firms; for the U.K. in Dahya et al. (2002), using 460 firms; and Franks et al. (2001) using 243 firms.

${ }^{2}$ Kaplan and Minton (2006) report an average CEO tenure of 5.7-6.4 years for the U.S. Similarly, we find an average CEO tenure of 6.8 years for the U.K. and 7.5 years for Germany.
} 
firms. The size of our sample is comparable to the largest U.S. data sets of CEO turnover. ${ }^{3}$

In our analysis, we find that CEO turnover is preceded by significant underperformance and followed by significant performance improvements. Governance mechanisms, in that sense perform a monitoring role, with respect to incumbent CEOs and oversee the selection of new CEOs, when such a decision is needed.

Our analysis is based on both operating performance measures and market-based performance measures and our results obtain for all of them. We are careful to adjust for mean reversion in operating performance, i.e. the fact that poorly performing firms in a given year experience larger future performance gains on average. We perform this adjustment in two ways. First, we follow Barber and Lyon (1996) and measure performance changes against control groups, that experience similar poor performance but no CEO turnover. Second, we use a dynamic panel data approach as in Blundell and Bond (1998), and control for unobserved firm heterogeneity and time effects in testing for post turnover performance. Importantly, while we observe significant mean reversion in corporate performance, our results show that mean reversion is not driving our results.

Surprisingly, the patterns of replacing a CEO in the event of poor performance, and realizing significant improvements in performance after a new CEO is appointed are virtually identical in the U.K. and in Germany. This is striking, since structural governance differences between the two samples are large. The U.K. represents a market-based system that shares most U.S. features - single tier boards, highly developed financial markets, firms that typically do not have blockholders, and few restrictions on corporate restructuring, including weak employment protection. Germany represents a relationship-based system and features mandatory two tier

\footnotetext{
${ }^{3}$ See Coughlan and Schmidt (1985), Warner et al. (1988), Weisbach (1988), Bonnier and Bruner (1989), Denis and Denis (1995), Khanna and Poulsen (1995), Fee and Hadlock (2004), Huson et al. (2004) and Kaplan and Minton (2006).
} 
boards, less developed financial markets, significant importance of (relationship) banks, firms that typically have a large blockholder, and some of the strongest employment protection in developed markets.

After establishing these baseline results, we proceed to test whether the relation between CEO turnover and firm performance is influenced by firm governance characteristics. We consider a large number of governance mechanisms previously proposed as important determinants of monitoring. We place space emphasis on board characteristics (board size, the percentage of outsiders on the board, the percentage of bankers on the board, CEO and Chairman separation), and shareholder characteristics (concentrated ownership and large blockholders, families, institutional shareholders).

In a nutshell, we do not find evidence that governance characteristics are associated with the likelihood of either removing underperforming incumbent CEOs or with hiring better incoming CEOs. Instead, boards and shareholders act indiscriminately. Empirically this means, for example, that outsider-dominated boards are neither more likely to fire a CEO after bad performance than after normal performance, nor are they associated with the appointment of new CEOs that bring about larger gains in corporate performance. In short, governance mechanisms appear to be mostly irrelevant for the successful turnarounds that firms experience. Interestingly, the lack of significant effects is not specific to one of the two financial systems in our sample, despite their large differences. For example, we do not find evidence of a monitoring role of institutional investors in the U.K. or of family blockholders or bankers sitting on a firm's board in Germany.

We do, however, find more similarities between the U.K. and Germany: Successful turnarounds under the new CEO coincide with large asset sales and significant layoffs. Again, 
the similarity of the results in both countries is remarkable, given that one might expect corporate restructuring in general and layoffs in particular to be more difficult to implement in Germany than in the U.K. Our evidence shows that this is not the case. Instead, incoming CEOs in both countries are able to implement significant downsizing plans. These are not only very similar between the two countries, but also similar to U.S. evidence[WE NEED A CITATION HERE]. The market for 'company doctors' hired as new CEOs also appears to be similar across countries. Like in the U.S., outside hires are rare and do not contribute to stronger downsizing, for example.

One possible concern is that governance quality may affect the credibility and effectiveness of the CEO turnover threat, but our governance measures are mismeasured. We address this concern by showing that many of the governance parameters we consider do affect how frequently CEO turnover occurs and how performance changes following prior declines, consistent with prior U.S. evidence. These results confirm the relevance of the governance variables that we use. At the same time, they support the view that CEO turnover and performance are both related to firm-specific governance mechanisms, such as board composition. For example, firms with small, outsider-dominated boards have a higher likelihood of CEO turnover than firms with large, insider-dominated boards. These effects also filter through to performance changes under the new CEO: Firms with outsider-dominated boards experience larger improvements in performance than firms with insider-dominated boards. However, these effects affect all firms irrespective of their performance.

Taken together, our results suggest that in times of crisis, the likelihood of a CEO being replaced increases and bringing in a new CEO causes a significant performance improvement. This economic mechanism appears to work in nearly identical ways in markets as similar as the 
U.S. and the U.K. and in markets as different as the U.K. and Germany. The bright side of these results for shareholders is that CEOs that perform particularly poorly are generally successfully replaced, and existing governance mechanisms are collectively sufficient for this to happen. ${ }^{4}$ However, the beneficial effects of CEO turnover do not result from any specific governance mechanism in isolation.

Our paper makes several contributions. First, we provide evidence that performance patterns around CEO turnover, that were shown for U.S. firms, also arise in other markets that lack the governance mechanisms that have been argued to determine performance around CEO turnover in the U.S. (as Germany does). They also arise in markets that do not lack the governance mechanisms, but the mechanisms are unrelated to firm performance around CEO turnover (as the evidence shows for the U.K.).

Second, we provide evidence that the beneficial effects of outsider dominated boards in CEO replacement decisions observed in the U.S. do not extend to the U.K. Prior results on whether outsiders contribute to making the turnover threat credible have been conflicting (Dahya et al., 2002, and Franks et al., 2001). To resolve this, we use the most detailed data available to date to determine whether directors are outsiders and to show that, independent of how strict we are in classifying outsiders, they neither increase the credibility of the turnover threat, nor do they improve CEO appointment decisions. Our study provides a larger, more recent sample, with finer criteria of director independence assessment than prior research, and shows that the benefits of outside directors are less general than U.S. evidence suggests.

\footnotetext{
${ }^{4}$ Although we quantify a firm's response to performance declines, we cannot observe whether underperforming CEOs are subject to pre-emptive firing, i.e. firing before performance declines. If firms with good governance always pre-emptively fire CEOs and firms with weak governance do not, then the lack of explanatory power of governance quality could be due to firings after performance declines only occurring in low quality governance firms, where governance is so weak that differences in quality are irrelevant. To rule out this concern we test for differences in governance quality between firms where CEO turnover occurs after normal performance and firms where CEO turnover occurs after underperformance; we do not find any such differences.
} 
Third, we address the concern of mean reversion in our analysis of how effective CEO replacements are in turning around poorly performing firms. Since turnover occurs more frequently in cases of prior underperformance, neglecting mean reversion may overstate the performance benefits of CEO turnover. We adopt a dynamic panel data approach to address biases induced by unobserved firm heterogeneity and persistence in operating performance. Any unobserved firm characteristic that is positively related to both future performance and current CEO turnover leads to an overstatement of turnover-related performance benefits for poorly performing firms. To the best of our knowledge, this issue has not been addressed in the existing literature on post-turnover performance changes.

Fourth, we provide the largest samples of CEO turnover for the U.K. and Germany so far, allowing us to address concerns of representativeness. Prior results for Germany in Kaplan (1994b) and for the U.K. in Franks et al. (2001) show no effect of the quality of governance on the sensitivity of CEO turnover to past performance. Our tests strongly support this and show no increase in the importance of governance quality in more recent data.

The remainder of the paper is structured as follows. In Section 2, we discuss related research and hypotheses. Section 3 presents the data used in our study and provides summary statistics. The empirical analysis and discussion of our results is contained in Section 4, and Section 5 concludes.

\section{Related Research and Hypotheses}

In this section we review prior research regarding the relation of firm performance and governance around CEO turnover events and develop our hypotheses.

Our basic premise follows Hermalin and Weisbach (1998), who propose a theoretical 
framework in which the board acts in the interests of shareholders and monitors the CEO. Performance declines lead the board to update its information about the quality of the CEO and in turn raise the probability that the board appoints a new $\mathrm{CEO}$, whose expected quality exceeds the incumbent CEO's quality. In this setting, the threat of CEO replacement is both credible and effective.

Empirical evidence confirms a credible threat in the U.S. Early studies by Coughlan and Schmidt (1985), Warner et al. (1988) and many later papers find a negative association between firm performance and management turnover. In the U.K., Dayha et al. (2002) and Franks et al. (2002) find a similar negative relation between firm performance and CEO turnover, while Kaplan (1994b) confirms the same pattern for CEOs in Germany. Similar results have been shown to arise in many other financial markets, which we do not review here for brevity.

There is also evidence that CEO replacement decisions are effective in U.S. firms. Denis and Denis (1995), Denis and Kruse (2000) and Huson et al. (2004) document significant improvements in operating performance following the turnover. There is little or no prior evidence for either Germany or the U.K. about turnover effectiveness.

What makes the threat both credible and effective? Technically, the board hires and fires the CEO and board independence is widely argued to be the key ingredient to boards removing underperforming CEOs. In addition, prior research has suggested board size and external mechanisms-monitoring by blockholders, price pressure from takeovers, and financial leverageas influencing the relation between CEO turnover and firm performance.

Can firm-level governance be expected to work in identical ways across countries? A primary reason for focusing on U.K. and German firms is that institutional differences between the two countries are significant, which prior research has argued to affect firm-level 
governance. Investor protection is stronger in the U.K. than in Germany. Similarly, financial development is high in the U.K. and low in Germany. Further, employment protection is weak in the U.K. and strong in Germany, creating presumably larger barriers against corporate restructuring and layoffs. ${ }^{5}$ If these institutional differences affect governance, they may also influence the relation between CEO turnover and performance. We discuss each of the internal and external mechanism mentioned above and expected country differences in turn.

Independence: Hermalin and Weisbach (1998) and many others argue that outside board directors are independent and play the role of monitors. This view has served as the basis of regulatory efforts internationally, including Sarbanes-Oxley in the U.S., the Cadbury Report in the U.K., and the Corporate Governance Code in Germany. Whether the board independence view applies is ultimately an empirical question and the evidence is mixed. In the U.S., outside directors have been shown to increase the sensitivity of turnover to past performance (see Weisbach, 1988, Borokhovich et al., 1996, Bhagat and Bolton, 2008). In the U.K., the evidence is ambiguous. Dahya et al. (2002) find a significant disciplinary role for outsider-dominated boards, while Franks et al. (2001) find no evidence of disciplining by outside board members. The latter authors suggest that regulatory differences between the U.S. and the U.K. may lead to the irrelevance of outsider board representation. In the U.S. directors have significant fiduciary obligations, whereas very few such obligations exist in the U.K. In Germany, supervisory board members have been argued to be either more or less independent than their U.S. counterparts

\footnotetext{
${ }^{5}$ At the beginning of our sample period in 1996, the antidirector rights index in Djankov et al. (2008) has a score of 5 in the U.K. and 1 in Germany, out of a maximum of 6; while the anti self dealing index is 0.95 in the U.K. and 0.28 in Germany, out of maximum of 1 . Regarding financial development, stock market capitalization relative to GDP is 119.5 percent in the U.K. and 21.8 percent in Germany; the number of listed firms relative to the country's population (in billion) is 35.2 in the U.K. and 8.3 in Germany; and the number of initial public offerings per year relative to the stock of listed firms is 9.1 percent in the U.K. and 2.9 percent in Germany (World Development Indicators, 1997). Regarding employment protection, strictness of employment protection legislation is 0.6 in the U.K. and 2.5 in Germany, against an OECD average of 2.0 (OECD Employment Outlook, 2008); strictness of employment laws is 1.02 in the U.K. and 1.57 in Germany, against a global average of 1.58 (Botero et al., 2004).
} 
(Roe, 1993, Fauver and Fuerst, 2006). If outsider dominated boards increase monitoring quality of boards, they should increase the sensitivity of turnover to past performance as well as lead to larger performance improvements following turnover. This conjecture applies to the U.K., but not to Germany, as the two-tier board structure of German firms does not allow to distinguish between insider and outsider dominated boards.

Board size: Large boards have been argued to adversely affect monitoring quality, because of free riding problems (Jensen, 1993). Yermack (1996) finds that firms with smaller boards are more likely to discipline poorly performing managers in the U.S., while Dahya et al. (2002) confirm this finding for the U.K. All firms in our German sample are subject to codetermination rules. No prior evidence exists for Germany and the U.K. whether board size affects performance under the new CEO. If smaller boards lead to more effective monitoring, smaller boards should increase the sensitivity of turnover to past performance and lead to larger performance improvements following turnover. Because firm discretion over board size is by law more limited in Germany than in the U.S. or the U.K. any empirical relation is expected to be weaker.

Monitoring by blockholders: Blockholders can potentially overcome free rider problems of monitoring and act as a disciplinary mechanism (Shleifer and Vishny, 1986). U.S. evidence suggests that the presence of blockholders increases the likelihood of turnover (Denis et al., 1997), and more strongly so in poorly performing firms after failed takeover bids (Denis and Serrano, 1996). Li and Srivnivasan (2011) find such disciplinary turnover is more pronounced in family firms. For the U.K. however, Franks et al. (2001) find no disciplinary effect of blockholders. For Germany, Kaplan (1994b) similarly does not identify any blockholder effect on turnover. Regarding post-turnover performance, Huson et al. (2004) find that institutional 
shareholdings are associated with larger profitability gains. There is no prior evidence for postturnover performance for the U.K. and Germany. Under the view that blockholders act as disciplinary agents, they should increase the sensitivity of turnover to past performance and lead to larger performance improvements following turnover. Blockholders throughout our sample period are relatively rare in the U.K. and frequent in Germany (Faccio and Lang, 2002, Franks et al., 2012). If the effect of blockholders per se is similar across countries, one would therefore expect a higher sensitivity of turnover to past performance and larger performance improvements in Germany.

Financial leverage: Debtholders may affect board firing and hiring decisions in two ways. First, Jensen (1986) argues that debt financing reduces free cash flow and therefore acts as a disciplinary device for managers. Second, banks providing debt financing may play an active monitoring role. Financing sources differ between Germany and the U.K., with bank financing playing a large role for German firms, often in the form of relationship banking (Franks and Mayer, 2001). In the U.K., debt is more likely to be public debt, while in Germany debt is more likely to assume the form of bank financing (Koeke, 2004). Leverage therefore might be expected to play a more important disciplinary role in Germany than in the U.K.

In addition, and to observe bank relationships more directly, we try to measure the board monitoring performed by banks. The expected monitoring of bankers is ambiguous. On the bright side, bankers may act as active monitors, as they may wish to safeguard their existing loans and have access to better monitoring technology and information. On the dark side, they may be supporters of the incumbent CEO. The overall effect is therefore ambiguous. There is no prior evidence on the effect of bank representation on boards for CEO turnover decisions, for the U.K. and for Germany. We follow Dittmann et al. (2010) and use the percentage of bankers on a 
firm's board as an indicator of the intensity of bank monitoring. ${ }^{6}$

Price pressure: The threat of a takeover may be sufficient to induce board members to preemptively discipline underperforming management (Hirshleifer and Thakor, 1994). Indeed, Mikkelson and Partch (1997) show that the sensitivity of turnover to performance in U.S. firms increases during periods of high takeover activity. More recently, however, this finding has been disputed by Huson et al. (2001). For the U.K., Franks et al. (2001) find no disciplinary effect of takeovers. For Germany, Koeke (2004) and Franks and Mayer (2001) find increased turnover following block transactions, but no evidence is provided on the relation to firm performance. Under the view that takeovers increase monitoring incentives for the board, stronger price pressure will increase the sensitivity of turnover to past performance and increase performance following turnover. Prior evidence by Franks and Mayer (2001) shows that takeovers are rarely hostile in Germany. Therefore, any disciplinary effect of takeovers is likely to be weaker.

\section{Sample and Summary Statistics}

Our sample ties together a number of different data sources. Firms are initially selected based on coverage by Compustat Global, which according to S\&P covers $95 \%$ of total European market capitalization. Between 1995 and 2005, Compustat reports data on roughly 3,500 firms in the U.K. and 1,100 firms in Germany. These firms are matched with our primary data sources of board data, which is the electronic Manifest database for the U.K. and the annual hardcopy issues of Hoppenstedt for Germany. For both countries we restrict data to firms that enter Compustat until 1997, by the latest. From the matched sample of firms we eliminate private firms, investment trusts (SIC codes 61 and 62), firms for which board composition is missing and firms

\footnotetext{
${ }^{6}$ Data availability on bank financing or bank relationships for most of our sample firms is scarce. To illustrate, our average sample firm has no coverage on either LPC Dealscan or Thomson Deals Analysis throughout the sample period.
} 
that have coverage gaps. The final sample contains 723 firms for the U.K. and 340 firms for Germany. To illustrate coverage, we compare our sample with the total market capitalization of listed domestic companies reported by the Worldbank: In 1997 our sample represents 54 percent of total market capitalization in Germany, and 48 percent of total market capitalization in the U.K.

\subsection{Board data}

To construct CEO turnover measures that are consistent between countries, we treat the chairman of the management board (Vorstandsvorsitzender) in Germany as equivalent to the CEO in the U.K. Executive directors in the U.K. correspond to management board (Vorstand) members in Germany and nonexecutive directors in the U.K. correspond to supervisory board (Aufsichtsrat) members in Germany.

We collect managerial turnover data by tracking firms over time in Manifest for the U.K. and in the annual issues of Hoppenstedt for Germany. CEO turnovers are classified into internal and external ones. Internal turnover for U.K. indicates that the CEO or Chairman resigns from his position, but stays on the board of directors, whereas external turnover means that they leave the board. Similarly, internal turnover for Germany indicates that the CEO or Chairman resigns from his position, but stays either on the management board or on the supervisory board. On top of this classification, we also classify whether the incoming CEO is externally hired, i.e. an outsider, or whether he or she previously worked for the firm. We take great care to correctly identify the relatively rare cases of true external appointment, by considering all prior positions a new CEO has had, including those that were below the board level. For this we review all 812 turnover cases and obtain incoming CEOs' biographies from BoardEx and complement them 
with news searches on Factiva. ${ }^{7}$

Under German corporate law, corporations are not required to have a CEO. While many firms choose to always appoint a CEO, some never choose to and some switch regimes over time. Under U.K. corporate law, corporations are required to have a CEO, but we observe firms without a CEO in some years. CEO changes therefore do not always correspond to true turnover events. We search all turnover event of on Factiva and eliminate events arising from firms switching regimes.

We collect information on CEO and Chairman age using Manifest for the U.K. and Capital IQ, Factiva and annual reports for Germany.

We record board size, the number of executive and nonexecutive directors and the names of CEO and Chairman on a yearly basis. For U.K. firms, we measure board size as the total number of executive and non executive directors reported by the Manifest database. For German firms we measure board size as the number of supervisory board members, reflecting the fact that management board directors do not participate in CEO dismissal and appointment decisions. Regarding board independence, we follow the U.K.'s Combined Code on Corporate Governance in classifying director independence. ${ }^{8}$ We construct three measures of board independence: The first relies on the firm's report on the independence of each director, based on the U.K. Corporate Governance Code criteria. Since corporations can circumvent those criteria, our

\footnotetext{
${ }^{7}$ We do not perform event study analyses of CEO turnover announcement returns, because scarce news coverage on Factiva does not allow to reliably identify the earliest announcement date for the majority of CEO turnovers in Germany.

${ }^{8}$ The U.K. Combined Code on Corporate Governance classifies a director as dependent if he or she i) has been an employee of the company or group within the last five years; ii) has had, within the last three years, a material business relationship with the company either directly, or as a partner, shareholder, director or senior employee of a body that has such a relationship with the company; iii) has received additional remuneration from the company apart from a director's fee, participates in the company's share option or a performance-related pay scheme, or is a member of the company's pension scheme; iv) has close family ties with any of the company's advisers, directors or senior employees; v) holds cross-directorships or has significant links with other directors through involvement in other companies or bodies; vi) represents a significant shareholder; or vii) has served on the board for more than nine years from the date of first election.
} 
second measure uses the assessment by Manifest of director independence, which applies the Code's criteria strictly. Finally, Shivdasani and Yermack (1999) show negative stock price reactions to independent director appointments, when the CEO is involved in the nominating committee. We therefore construct a third measure of board independence which classifies directors as insiders if they are appointed after the appointment date of the CEO. ${ }^{9}$ We do not construct board independence measures for Germany, since the roles of the supervisory and management board members are legally separated.

A final dimension in which board structures differ is that in Germany the representation that banks enjoy on the board is higher and more frequent, in line with the view that the German system is a bank-based financial system. To examine the role of bankers in CEO appointment and replacement decisions, we construct the ratio of board members that are affiliated with a bank. The information for this variable is available for a subsample of 114 German firms as used in Dittmann et al. (2010) and kindly provided by the authors, and from Manifest for all U.K. sample firms.

\subsection{Firm-level data}

Along with board composition data, we collect yearly shareholder data for all sample firms. We collect all shareholder stakes larger than 5\% and aggregate them by blockholder in case an ultimate controlling blockholder holds several stakes directly and indirectly. For both countries, a company is considered widely held when no shareholder owns more than $25 \%$ of voting rights. Otherwise the firm is regarded as controlled by a block shareholder. We further classify blockholders by type into institutional investors, families, industrial blockholders, and others,

\footnotetext{
${ }^{9}$ Perry (2000) shows that incentive compensation for independent directors increases the likelihood of CEO turnover following poor performance. We have experimented by eliminating the third criterion in the U.K. Corporate Governance Code, and results remain unchanged.
} 
where the latter includes non-family controlled foundations, the state, employees, and management). Shareholders are identified (and traced to ultimate blockholders if these exist) using Manifest and Hoppenstedt data, augmented by Factiva, annual reports and web searches. In addition to these variables we construct alternative versions that combine our data with the widely used data on shareholdings and ultimate ownership provided in Faccio and Lang (2002). Their data set has a slightly lower threshold (20\%) of voting rights and therefore identifies additional blockholders. In these alternative versions we treat a firm as having a blockholder if our data or the Faccio and Lang data indicate that a blockholder exists.

We also record time series of restructuring activities that take place at the firm level. We focus on asset and employment changes using Compustat and trace incidents of divestitures and acquisitions using SDC Platinum.

Stock return data, adjusted for dividends and splits, are obtained from Datastream. To calculate abnormal stock returns, we use country specific Fama French risk factors compiled by Ang et al. (2009) and kindly provided by the authors. Finally, all accounting items are obtained from Compustat Global and deflated to US\$ in 2000.

\subsection{Descriptive statistics}

Table 1 reports sample summary statistics. As Panel A shows, firm size and profitability of firms in the U.K. and Germany are very similar. The median firm has total market capitalization of \$280 million in the U.K. and \$240 million in Germany, and return on assets of 13 percent in the U.K. and 12 percent in Germany. As previously stated, a primary reason for focusing on U.K. and Germany is that large institutional differences exist between the two countries, which are reflected in many firm characteristics, including leverage and shareholder structures. Median 
leverage (total debt over assets) is 54 percent in the U.K. and 69 percent in Germany. The median firm does not have a blockholder with at least a 25 percent stake in the U.K., while it does in Germany. The largest shareholder controls 12 percent of voting rights in U.K. firms and 52 percent in Germany. Following from this, the most frequent types of blockholders-families and financial firms - are present in 6 percent (families) and 4 percent (financials) of firms in the U.K., and in 27 percent (families) and 9 percent (financials) in Germany.

Moving to board characteristics, Panel B shows that these are similar across countries, with two exceptions. First, German boards are larger on average, primarily due to labor representation on the supervisory board. ${ }^{10}$ Second, separation of the roles of Chairman and CEO is mandatory in Germany. In the U.K. no mandatory separation exists, but the majority of firms choose to separate these roles.

Turnover probabilities in Panel C are almost identical across countries, with mean total turnover of 16 percent in the U.K. and 15 percent in Germany. External turnover, where the outgoing CEO leaves the board, is 11 percent in both countries. Internal turnover, where the outgoing CEO stays on the board, is 4 percent in both countries. Finally, new CEOs are typically insiders, in both countries. The likelihood of appointing an incoming CEO who has not held any position in the company previously is 34 percent in the U.K. and 30 percent in Germany.

\section{Empirical Analysis}

In this section, we test whether the threat of CEO turnover is credible and effective in the U.K. and in Germany and whether or not the quality of firm-level governance improves both relations.

\footnotetext{
${ }^{10}$ Under German codetermination regulation, 50 percent of the members of the supervisory boards of corporations are appointed by employees, see Mitbestimmungsgesetz of 4 May 1976. This applies for companies with more than 2000 employees (for smaller companies mandatory representation is 30 percent, see Betriebsverfassungsgesetz of 15 January 1972, replaced by Drittelbeteiligungsgesetz of 18 May 2004).
} 
For the analysis we use our panel dataset over the period 1995-2005 that includes 812 CEO changes for 723 U.K. and 309 German firms. In Section 4.1 we first report results of a univariate analysis of the sensitivity of CEO turnover to past performance, where we introduce our four performance measures - return on assets (ROA), industry-adjusted return on assets (IAROA), control-group adjusted return on assets (CGAROA), and abnormal stock returns $(A R)$. Then, we examine whether turnover sensitivities differ between the two countries in a multivariate analysis with additional firm-specific controls. Having established these baseline results, we turn to the analysis of the effect of CEO turnover on future performance in Section 4.2. In this analysis we explicitly address the possibility that operating performance is subject to unobserved heterogeneity and persistence in operating performance and use GMM-type panel estimators proposed by Blundell and Bond (1998). We also provide evidence of the extent of corporate restructuring that follows CEO turnover and coincides with consequent performance changes. Finally, we introduce measures of firm-level governance quality and explore in detail whether the quality of governance in any way influences the sensitivity of turnover to past performance (i.e. the board's firing decision) in Section 4.3, and the performance changes following the turnover (i.e. the board's hiring decision) in Section 4.4. Finally, we explicitly test whether any differences exist across countries with respect to the importance of these governance mechanisms for the firing and hiring decisions taken by boards.

\subsection{Sensitivity of Turnover to Past Performance}

In Table 2, we examine how prior firm performance affects CEO turnover decisions. Under the effective monitoring view, CEOs should be relatively more likely to be replaced after poor performance. To test this, firms are divided into performance quintiles, where quintiles are based 
on our four performance measure, $R O A, I A R O A, C G A R O A$ and $A R$, and quintile cutoff values are determined per country.

$R O A$ is calculated as EBITDA over lagged total assets. IAROA is equal to ROA minus the the two-digit SIC code industry median. This industry median is determined using a minimum of three firm-year observations in the same two-digit industry. If less than three observations are available, the industry-median is determined at the one-digit industry level. IAORA is missing if less than three firm-year observations are available at the one-digit industry level. CGAROA is control group adjusted $R O A$, and follows the approach proposed by Barber and Lyon (1996) and previously used in managerial turnover studies by Denis and Kruse (2000) and Huson et al. (2004). This methodology compares the performance changes a given firm experiences following a turnover event with the performance changes of other firms in the same industry and with roughly the same performance in the year preceding turnover. More precisely, the control group adjusted change in $R O A$ for firm $i$ which experiences turnover is computed as:

$$
\Delta \operatorname{CGAROA}_{i}=\Delta R O A_{i}-\operatorname{Median}\left(\triangle R O A_{k} \mid k \in G_{i}\right)
$$

where $G_{i}$ is the set of comparison firms for firm $i$ in the year of turnover. This set comprises the firms which satisfy three criteria: i) The firm is covered by Compustat Global. ii) ROA is within \pm 2 percentage points of $R O A$ of the matching firm in the fiscal year preceding the turnover event. iii) The firm is incorporated in the same country and belongs to the same industry as company $i$.

Comparison firms are in the same two-digit SIC code industry as firm $i$. If no matching firm in the same industry is found, the control group is defined at the one-digit SIC industry level. If no matching firm is found at the one-digit level, CGAROA is missing.

The three operating performance measures, ROA, IAROA and CGAROA are measures of 
short-term profits and therefore better predictors of CEO turnover than stock market returns, if the market incorporates future benefits of replacing an underperforming CEO. Stock price data and our measure of abnormal stock price performance, $A R$, may therefore underestimate the amount of monitoring by the board. At the same time, earnings data have many potential problems when used as profitability measures. Because of this we follow Weisbach (1988) and later studies and use both stock market based and accounting based performance measures.

Table 2 shows three main results. First, the sensitivity of external turnover to past performance is very similar between the two countries. In Panel A, moving from the highest to the lowest $R O A$ performance quintile increases the likelihood of external CEO turnover from 9 to 17 percent in the U.K., and from 8 to 14 percent in Germany. Using IAROA, the likelihood of external CEO turnover increases from 9 to 16 percent in the U.K., and from 7 to 16 percent in Germany. Results for CGAROA and market-based $A R$ are very similar.

Second, the increase in CEO turnover probability from the highest to the lowest performance quintile is statistically significant in all four panels (although significance is only marginal for CGAROA in Panel C), in both countries. Therefore, as performance declines, CEOs face an increasing likelihood of being removed by the board.

Third, internal turnover does not vary with performance in either country. Recall that internal turnover indicates CEO turnover events where the outgoing CEO stays in the firm. The lack of sensitivity to past performance in this CEO turnover category confirms that if the CEO stays in the firm, the turnover cannot plausibly be a firing. Instead, many of these events correspond to turnover due to health, retirement and other reasons unrelated to performance, and do not represent meaningful turnover events in the spirit of our analysis. Therefore, in the remainder of our analysis we only consider external turnover events, and treat firm-year 
observations with internal turnover events as firm years without turnover event.

These univariate results are confirmed by multivariate regressions in Table 3 , where the dependent variable is whether (1) or not (0) an external CEO turnover occurs in a given firm year. All regressions include as additional control variables firm size (log of total assets), CEO age, and indicator variables for unknown CEO age, financial firms, and year fixed effects. Columns 1, 3, 5 and 7 include the previous four performance variables-ROA, IAROA, CGAROA, AR, while columns 2, 4, 6 and 8 additionally include an interaction of the performance variable with an indicator variable for firms incorporated in Germany. All performance variables have the expected negative coefficient, indicating that external CEO turnover likelihood increases as performance declines and all are significant at the 1 percent level or better. In contrast, the interaction term with the indicator variable for Germany is never significant, showing that the sensitivity of turnover to performance is never significantly different, even marginally, between the two countries.

\subsection{Post-turnover corporate performance}

To what extent does CEO turnover lead to improvements in corporate performance? To answer this question, it is necessary to distinguish turnover incidents in underperforming firms from those in normally performing firms. We expect performance improvements to be more pronounced in the former group of firms, where the likelihood of disciplinary turnover is higher. Operating performance however exhibits mean reversion: Firms with low performance experience larger performance gains than firms with normal performance do. As we have shown, turnover occurs more frequently in cases of poor prior performance. Neglecting this mean reversion may therefore overstate the performance benefits of CEO turnover. To correct for 
mean reversion in $R O A$, we follow the previously described control group adjustment methodology proposed by Barber and Lyon (1996) in constructing CGAROA.

Figure 1 reports operating and stock performance in the seven year period surrounding turnover events. For the pooled sample, which contains both normal and underperforming firms, operating performance, measured by ROA, IAROA, and CGAROA, is flat throughout the seven year period. Abnormal stock returns, $A R$, similarly remain roughly unchanged during the seven year window. When we consider poorly performing firms however, (i.e. firms in the bottom quintile of performance), we find that both operating and stock performance decline prior to turnover and reverse sharply afterwards. Patterns for firms in Germany and in the U.K. are similar.

To quantify the significance of these effects, Table 4 reports the results of a univariate analysis of the effect of turnover on future performance. The median changes in ROA, IAROA and CGAROA, in the three years following the removal of the CEO, are $11.9 \%, 6.9 \%$ and $12.2 \%$ for U.K. firms and 7.9\%, 5.5\% and 6.9\% respectively for German firms. These performance improvements are statistically significant at the five or at the one percent level, either considering the pooled sample, or the subsamples of U.K. and Germany. Operating performance improvements are slightly less pronounced for Germany when operating performance is adjusted for mean reversion, but the U.K. and Germany are never statistically different from each other, at the 10 percent level. When we consider abnormal returns, we find that performance improvements are remarkably close: A median of $48 \%$ in the U.K. and $50 \%$ in Germany, with the difference again not being significant.

These results provide preliminary evidence of post-turnover performance improvements for underperforming firms in both countries. However, two important issues regarding 
unobserved heterogeneity and operating performance dynamics need to be addressed. With respect to the former, any unobserved firm characteristic that is positively correlated to both future performance and current CEO turnover would lead to an overstatement of the turnover benefits for underperforming firms. Regarding the second issue, mean reversion may still be present even after control group adjusting if $R O A$ exhibits autocorrelation of order higher that one. We provide evidence below that this is indeed the case in our sample.

To the best of our knowledge, neither issue has been addressed in the existing literature on post-turnover performance changes. By now standard econometric results (see Arellano and Bond (1991)) show that dynamic panel data models cannot be estimated consistently by the usual fixed effects estimators, since the set of regressors are by construction not strictly exogenous. Because of this, we make use of the GMM-type estimator proposed by Blundell and Bond (1998) and describe briefly its implementation in our analysis below.

The model to be estimated is of the form:

$$
y_{i t+1}=a_{0}+a_{1} y_{i t}+a_{2} y_{i t-1}+\beta^{\prime} x_{i t}+\gamma^{\prime} d_{t}+\eta_{i}+\varepsilon_{i t}
$$

where the dependent variable, $y_{i t+1}$, is future performance measured by ROA, IAROA, and CGAROA , $x_{i t}$ is a vector of regressors, $d_{t}$ is a set of year dummies, $\eta_{i}$ captures fixed unobserved firm heterogeneity, and $\varepsilon_{i t}$ is a white noise disturbance. We assume that $E\left(\eta_{i}\right)=E\left(\varepsilon_{i t}\right)=E\left(\varepsilon_{i t} \eta_{i}\right)=E\left(\varepsilon_{i t} \varepsilon_{i s}\right)=0$, for every $t \neq s, E\left(\varepsilon_{i t}^{2}\right)=\sigma_{\varepsilon}^{2}<\infty, E\left(\eta_{i t}^{2}\right)=\sigma_{\eta}^{2}<\infty$ and $E\left(y_{i 1} \varepsilon_{i t}\right)=0$ for every $\mathrm{t}>1$. Letting $u_{i t}=\eta_{i}+\varepsilon_{i t}$, the Blundell and Bond estimator is a linear optimal GMM estimator, it makes use of the orthogonality conditions: $E\left(y_{i, t-s} \Delta \varepsilon_{i t}\right)=0$ for $s>1$, and $E\left(u_{i t} \Delta y_{i, t-1}\right)=0$ for $t \geq 3$. In the estimation procedure, the year dummies $d_{t}$ are treated as strictly exogenous, whereas the regressors $x_{i t}$ as predetermined. 
Table 5 presents the estimation results that include year fixed effects and firm fixed effects. $^{11}$ We define poorly performing firms $(Q L O W)$ as those in the bottom performance quintile. By interacting $Q L O W$ with a turnover dummy variable, we examine the effect of turnover on future performance separately for firms with poor prior performance and for firms with normal prior performance. In all regressions, additional control variables include the log of total assets, the log change in total assets, the log of number of employees, and the log change of the number of employees.

The coefficients of the interaction term of $Q L O W$ with CEO turnover are always positive and significant. The triple interaction with the indicator for Germany is insignificant in two out of three cases. The results indicate that in both countries underperforming companies enjoy performance improvements in all measures of operating performance, over and above all effects induced by mean reversion, firm growth at the year of turnover, unobserved firm heterogeneity and year-specific shocks. Despite their differences in governance characteristics, both financial systems are successful in implementing turnover decisions that reverse the course of poorly performing firms.

The similarity between the two countries is further manifested when we examine corporate restructuring measures associated with turnover decisions. Table 6 shows that in both countries of our sample, a CEO change is followed by large asset sales and employment reductions, especially when turnover takes place in a poorly performing firm. This is consistent with the evidence in Weisbach (1995), who shows that CEO turnover leads to increased divestitures. For those firms, in the three year period following turnover, the median percentage change in asset size is $-5.8 \%$ in the U.K. and $-20.6 \%$ in Germany. Similarly the median

\footnotetext{
${ }^{11}$ Note that country fixed effects and firm fixed effects can be estimated separately, since a subset of the orthogonality conditions, $E\left(u_{i t} \Delta y_{i, t-1}\right)=0$, makes use of the level rather than the differences of disturbances.
} 
percentage change in employment is $-15.1 \%$ in the U.K. and $-15.2 \%$ in Germany. The case of Germany is especially noteworthy, since strong employment protection legislation and labour participation in the supervisory board apparently do little to block extensive restructuring after a CEO turnover event.

\subsection{Governance and CEO turnover}

How are CEO turnover decisions related to firms' governance characteristics? We consider two broad dimensions of corporate governance: board characteristics and ownership characteristics, as well as price pressure from takeovers and financial leverage.

We first consider the possible impact of governance quality on the sensitivity of CEO turnover to past performance. The results of probit regressions, where the dependent variable is CEO turnover, are reported in Table 7. In Panel A, lagged firm performance is interacted with board size, the three measures of board independence discussed in Section 3.1, the ratio of board seats occupied by bank executives and a dummy variable indicating separation between CEO and Chairman roles.

If directorships matter for CEO monitoring, we expect the sensitivity of turnover to prior performance to vary negatively with board size and positively with independence and possibly banker representation on board. We find that the frequency of turnover is related negatively to board size and positively to two of the measures of board independence. This is robust to controlling for year effects, firm size, and excluding the case of board independence, country differences between UK and Germany. Remarkably, however, none of the board structure measures considered affects significantly the sensitivity of turnover to prior performance. In unreported regressions we also consider financial leverage as an alternative measure of lender 
monitoring and governance quality, but do not find any significant economic effect.

The results show that although board size and independence are relevant for assessing the variation of CEO turnover across firms, they do not explain the extent to which turnover is used as a disciplinary mechanism to prevent performance declines. In firms in which the roles of CEO and Chairman are separated, we find that CEO turnover is more frequent. This characteristic however, is unrelated to monitoring. The sensitivity of turnover to prior performance in firms with a Chairman/CEO role separation is insignificantly lower, rather than higher, compared to the rest of the firms.

We obtain similar results when we consider the effect of ownership structures on disciplinary turnover in Panel B. Indeed, no corporate ownership characteristic, including the presence of a blockholder, the degree of ownership concentration, the extent of family ownership or institutional ownership is significantly related to either the frequency or the sensitivity of turnover to prior performance. These results obtain irrespective of whether we use ownership variables that are constructed using the Hoppenstedt and Manifest sources, or whether we use the alternative versions augmented with the Faccio and Lang (2002) data.

We also consider the disciplinary effect of price pressure due to takeovers. As outlined in our hypotheses, we expect takeovers to increase the sensitivity of turnover to past performance. We use takeover data from SDC and measure price pressure by i) the number of completed takeovers in the two-digit SIC industry of the firm ii) the number of completed hostile takeovers in the two-digit SIC industry of the firm and iii) the number of announced (but not necessarily completed) takeovers in the two-digit SIC industry of the firm, always per country and per year. In unreported regressions we find that none of these variables however increase the sensitivity of turnover to past performance. 
We conclude that although several governance characteristics are related to turnover frequency, they do not explain the extent to which turnover is associated with CEO disciplining.

\subsection{Corporate governance effects on post-turnover corporate performance}

If governance mechanisms do not consistently explain the likelihood with which poorly performing CEO is fired, do they explain which CEO turnovers lead to corporate turnarounds? To answer this question, we perform panel regressions that are similar to those in Table 5, where the dependent variable is future performance. Additionally, we now interact the measures of governance quality with a dummy variable indicating turnover in a low performing firm (Turnover x $Q L O W$ ) in Table 8.

In Panel A we examine how post-turnover performance, measured by industry adjusted $R O A$, varies with board structure, using a dynamic panel data framework. ${ }^{12}$ Consistent with Yermack (1996), we find that firms with large board size experience lower future profitability after controlling for firm size and growth. However, the interaction term between board size and turnover for poorly performing firms is insignificantly negative. Therefore there is little evidence that board size affects the dynamics of performance following a disciplinary turnover incident.

The composition of the board of directors is also likely to affect the criteria of CEO succession. For instance, independent directors are more likely to favor external appointments than inside directors. In addition, independent directors have less of their human capital attached to a specific firm, which in principle could make their attitude more favorable towards candidates bound to implement cost-cutting measures after their appointment. Our evidence suggests that firms with higher board independence experience lower future profitability. This

\footnotetext{
${ }^{12}$ We re-run all 13 regression specifications in Table 8 with our alternative performance measures $R O A$ and CGAROA. The results are very similar and do not yield additional insights, we omit them for brevity.
} 
result does not contradict the idea that outsider directors perform a monitoring role, since it may well be the case that firms appoint outsider directors when tough periods are expected in the near future. However, we find that the presence of independent directors is associated with larger future profitability when a turnover decision is taken in a normally performing firm, and with lower future profitability when that decision is taken in a poorly performing firm. In that sense, independence is relevant for quality of succession in normally performing firms, but it is not related to successful corporate turnarounds.

Regarding the effect of creditor representation on the board of directors, bank executives are clearly outside directors, and as such are less likely to agree with a succession plan that preserves private benefits of insider directors. Creditors however own a concave claim in the firm's asset value, and are likely to distort investment decisions away from risky projects. Our evidence suggests that banker representation is weakly positively related to future profitability, following a turnover in poorly performing firms. This effect is statistically significant only at the $10 \%$ level and therefore it is not a robust predictor of corporate turnarounds. In unreported results, we also test whether the relation between bank representation on board and post turnover performance varies with the financial leverage of the firm. The underlying idea is that creditor monitoring should be more pronounced when creditors have more 'skin in the game'. Our results however do not support this hypothesis.

We also examine whether separating the roles of CEO and Chairman is related to corporate turnarounds in the years following CEO turnover. Our evidence suggests that whereas poorly performing firms experience better operating performance in case the roles of CEO and Chairman are separated, those gains in performance are unrelated to whether the CEO is changed or not. Although the presence of a Chairman, as a director separate from the CEO, is potentially 
an important governance tool for reshaping poorly performing firms, its role does not take effect through the selection of replacement CEOs.

In a similar fashion, when we examine the effects of ownership characteristics on postturnover performance in Panel B, we find that some of these characteristics are in general related to performance. For example, family firms tend to have higher profitability, and firms with high institutional ownership lower profitability. However when we interact ownership characteristics with performance, we find no significant result, irrespective of whether the turnover takes place in a poorly or in a normally performing firm.

In unreported regressions we also consider the possible effect of price pressure due to takeovers as in Table 7, and use the takeover intensity variables described there. We do not find any significant effects of price pressure on improvements in performance following CEO changes.

At this point, the question emerges to what extent the above results may mask country specific differences? To address this, we re-examine in Table 9 how post turnover gains differ with board and ownership characteristics for each country separately. Our analysis excludes board independence and Chairman/CEO separation in Germany, since legal restrictions rule out any firm-wide variation in these measures (see section 3.3). Confirming our earlier results, we

find that corporate turnarounds following CEO turnover are not systematically related to governance variables either in Germany or in the UK, irrespective of the characteristic or the data source considered.

\section{Conclusion}

Our paper analyzes firm performance around CEO turnover events for a large sample of 5,300 
firm-year observations from the U.K. and Germany. We investigate whether underperformance leads to CEO turnover (the sensitivity of turnover to past performance) and whether CEO turnover leads to future performance improvements (the sensitivity of future performance to turnover), and whether both relations are strengthened by better governance.

The striking result to emerge from our analysis is that the basic economic mechanism of replacing the $\mathrm{CEO}$ in an underperforming firm to achieve a successful turnaround, appears to work well and in nearly identical ways across very different financial markets. It also appears to apply in virtually the same way across firms with very different quality levels of governance. On the bright side, our results therefore suggest that in times of crisis, boards on average take the right decisions. They also suggest however that strengthening a specific governance mechanism in isolation will not have beneficial effects, at least with respect to firing and hiring the CEO.

One particular aspect of our analysis is the (lack of a) role of outsider-dominated boards. Prior U.S. evidence shows that boards are more likely to take the right decisions when they are outsider-dominated. We find that boards in the U.K. take similar decisions to those in the U.S., but it does not matter whether they are outsider-dominated or not. Further, even boards in Germany take similar decisions, where because of two-tier board structures there are no crosssectional differences in outsider-domination and substitute governance mechanisms do not matter either. Our evidence suggests that the beneficial effects of outsider-dominated boards are limited to the U.S., or that outsider dominance in U.S. boards may not be causal but only related to other unobservable board characteristics. 


\section{References}

Ang, Andrew, Robert J. Hodrick, Yuhang Xing, and Xiaoyan Zhang, 2009. "High idiosyncratic volatility and low returns: International and further U.S. evidence", Journal of Financial Economics 91, 1-23.

Arellano, Manuel, and Stephen Bond, 1991. "Some Tests of Specification for Panel Data: Monte Carlo Evidence and an Application to Employment Equations", Review of Economic Studies 58, 277-297.

Barber, Brad M., and John D. Lyon, 1996. "Detecting abnormal operating performance: The empirical power and specification of test statistics", Journal of Financial Economics 41, 359399.

Bhagat, Sanjai, and Brian Bolton, 2008. "Corporate governance and firm performance”, Journal of Corporate Finance 14, 257-273.

Blundell, Richard, and Stephen Bond, 1998. "Initial conditions and moment restrictions in dynamic panel data models", Journal of Econometrics 87, 115-143.

Bonnier, Karl-Adam, and Robert F. Bruner, 1989. "An analysis of stock price reaction to management change in distressed firms", Journal of Accounting and Economics 11, 95-106.

Borokhovich, Kenneth A., Robert Parrino, and Teresa Trapani, 1996. "Outside Directors and CEO Selection”, Journal of Financial and Quantitative Analysis 31, 337-355.

Botero, Juan, Simeon Djankov, Rafael Porta, and Florencio C. Lopez-De-Silanes, 2004. "The Regulation of Labor", Quarterly Journal of Economics 119, 1339-1382.

Coughlan, Anne T., and Ronald M. Schmidt, "Executive compensation, management turnover, and firm performance: An empirical investigation", Journal of Accounting and Economics 7, 4366.

Dahya, Jay, John J. McConnell, and Nickolas G. Travlos, 2002. "The Cadbury Committee, Corporate Performance, and Top Management Turnover”, Journal of Finance 57, 461- 483.

Defond, Mark L., and Mingyi Hung, 2004. "Investor Protection and Corporate Governance: Evidence from Worldwide CEO Turnover", Journal of Accounting Research 42, 269- 312.

Denis, David J., and Diane K. Denis, 1995. "Performance Changes Following Top Management Dismissals", Journal of Finance, 50, 1029-57.

Denis, David J., and Jan M. Serrano, 1996.“Active investors and management turnover following unsuccessful control contests”, Journal of Financial Economics 40, 239-266.

Denis, David J., and Timothy A. Kruse, 2000. "Managerial Discipline and Corporate Restructuring Following Performance Declines", Journal of Financial Economics, 55, 391-424. 
Denis, David J., Diane K. Denis, and Atulya Sarin, 1997. "Managerial Incentives and Corporate Diversification Strategies", Journal of Applied Corporate Finance 10, 72-80.

Dittman, Ingolf, Ernst Maug, and Christoph Schneider, 2010, "Bankers on the Boards of German Firms: What They Do, What They Are Worth, and Why They Are (Still) There", Review of Finance 14, 35-71.

Djankov, Simeon, Rafael La Porta, Florencio Lopez de Silanes, and Andrei Shleifer, 2008, “The law and economics of self-dealing”, Journal of Financial Economics 88, 430-465.

Faccio, Mara, and Larry H. P. Lang, 2002. "The ultimate ownership of Western European corporations", Journal of Financial Economics 65, 365-395.

Fauver, Larry, and Michael E. Fuerst, 2006. "Does good corporate governance include employee representation? Evidence from German corporate boards", Journal of Financial Economics 82, 673-710.

Fee, C. Edward, and Charles J. Hadlock, 2004. "Management turnover across the corporate hierarchy", Journal of Accounting and Economics 37, 3-38.

Franks, Julian, and Colin Mayer, 2001. "Ownership and Control of German Corporations", Review of Financial Studies 14, 943-977.

Franks, Julian, Colin Mayer, and Luc Renneboog, 2001. "Who Disciplines Management in Poorly Performing Companies?”, Journal of Financial Intermediation 10, 209-248.

Franks, Julian, Colin Mayer, Paolo F. Volpin and Hannes F. Wagner, 2012. "The Life Cycle of Family Ownership: International Evidence", Review of Financial Studies, forthcoming.

Gibson, Michael S., 2003. "Is Corporate Governance Ineffective in Emerging Markets?", Journal of Financial and Quantitative Analysis 38, 231-250.

Hermalin, Benjamin E., and Michael S Weisbach, 1998. "Endogenously Chosen Boards of Directors and Their Monitoring of the CEO”, American Economic Review 88, 96-118.

Hirshleifer, David, and Anjan V. Thakor, 1994. "Managerial performance, boards of directors and takeover bidding", Journal of Corporate Finance 1, 63-90.

Hotchkiss, Edith S., 1995. "Postbankruptcy Performance and Management Turnover", Journal of Finance, 50, 3-21.

Huson, Mark R., Paul H. Malatesta, and Robert Parrino, 2004. "Managerial succession and firm performance", Journal of Financial Economics, 74, 237-275. 
Huson, Mark R., Robert Parrino, and Laura T. Starks, 2001. "Internal Monitoring Mechanisms and CEO Turnover: A Long-Term Perspective", Journal of Finance 56, 2265- 2297.

Jensen, Michael C., 1986. "Agency Costs of Free Cash Flow, Corporate Finance and Takeovers", American Economic Review 76, 323-329.

Jensen, Michael C., 1993. "The Modern Industrial Revolution, Exit, and the Failure of Internal Control Systems", Journal of Finance 48, 831-880.

Jenter, Dirk, and Katharina Lewellen, 2010. "Performance-induced CEO Turnover", Working Paper Stanford University and Dartmouth College.

Kaplan, Steven N, 1994a. "Top Executive Rewards and Firm Performance: A Comparison of Japan and the United States", Journal of Political Economy 102, 510-46.

Kaplan, Steven N, 1994b. "Top Executives, Turnover, and Firm Performance in Germany", Journal of Law, Economics and Organization 10, 142-59.

Kaplan, Steven N., and Bernadette Minton, 2006. "How has CEO Turnover Changed? Increasingly Performance Sensitive Boards and Increasingly Uneasy CEOs", NBER Working Papers 12465.

Khanna, Naveen, and Annette B. Poulsen, 1995. "Managers of Financially Distressed Firms: Villains or Scapegoats?", Journal of Finance 50, 919-40.

Koeke, Jens, 2004. "The market for corporate control in a bank-based economy: a governance device?", Journal of Corporate Finance 10, 53-80.

Lel, Ugur, and Darius P. Miller, 2008. "International Cross-Listing, Firm Performance, and Top Management Turnover: A Test of the Bonding Hypothesis", Journal of Finance 63, 1897-1937.

Li, Feng, and Suraj Srinivasan, 2011. "Corporate Governance When Founders Are Directors", Journal of Financial Economics 102, 454-469.

Mikkelson, Wayne H. and M. Megan Partch, 1997. "The decline of takeovers and disciplinary managerial turnover", Journal of Financial Economics 44, 205-228.

Perry, Tod, 2000. "Does the structure of board compensation matter? Evidence from CEO turnover", Working Paper Indiana University.

Roe, Mark J., 1993. "Some Differences in Corporate Structure in Germany, Japan, and the United States", Yale Law Journal 102, 1927-2003.

Shivdasani, Anil and David Yermack, 1999, "CEO involvement in the selection of new board members: an empirical analysis", Journal of Finance 54, 1829-1853. 
Shleifer, Andrei and Robert W Vishny, 1986. "Large Shareholders and Corporate Control", Journal of Political Economy 94, 461-88.

Warner, Jerold B., Ross L. Watts, and Karen H. Wruck, 1988. "Stock prices and top management changes", Journal of Financial Economics 20, 461-492.

Weisbach, Michael S., 1988. "Outside directors and CEO turnover", Journal of Financial Economics 20, 431-460.

26

Weisbach, Michael S., 1995. "CEO Turnover and the Firm's Investment Decisions", Journal of Financial Economics 37, 159-188.

Yermack, David, 1996. "Higher Market Valuation of Companies with a Small Board of Directors", Journal of Financial Economics 40, 185-211. 


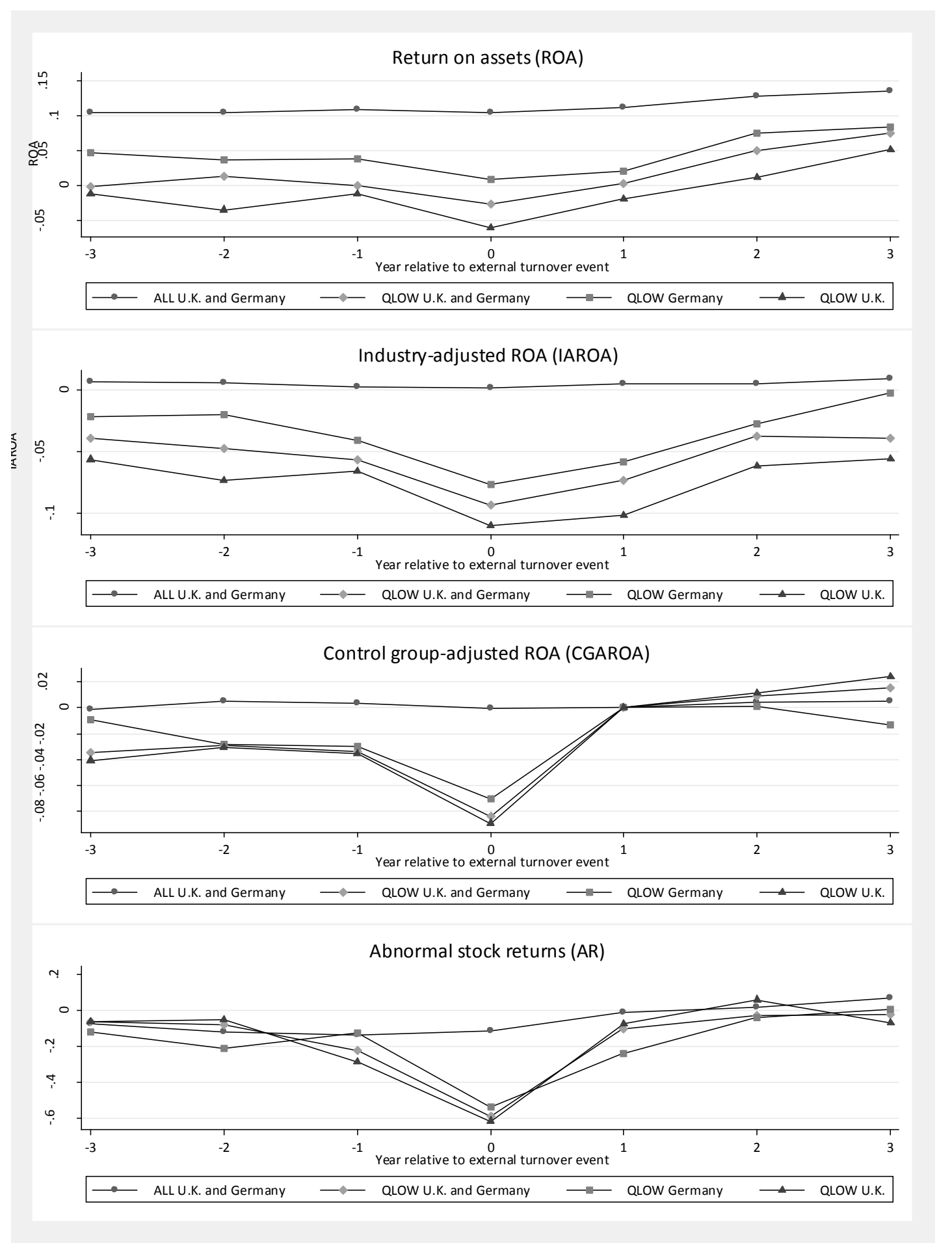

\section{Figure 1: Firm Performance Around CEO Changes}

Firm performance around external managerial turnover events. Year 0 is the fiscal year during which the turnover takes place. ALL indicates all turnover cases, $Q L O W$ indicates turnover cases where the firm belongs to the lowest performance quintile in the year prior the event. Performance is measured by return on assets $(R O A)$, industryadjusted ROA (IAROA), ROA adjusted by a matched control group of firms (CGAROA) and abnormal stock returns $(A R)$. All performance measures are defined in Table 2. For each performance measure turnover events are restricted to those for which firm performance data is available for the full 7-year window centered on the turnover year. 
Table 1. Descriptive Statistics

Summary statistics for the main variables used in the analysis, for the sample period 1995 to 2004. Sales and Assets are in billions of US\$; Employees are in thousands; Leverage is total debt over total assets, for non-financial firms only; $R O A$ is EBITDA over lagged total assets; Abnormal stock returns are risk-adjusted annual returns using a local Fama French three factor model, where returns are dividend and stock split adjusted and factor loadings are estimated using monthly returns over the 24 month period preceding the fiscal year; Large blockholder, family blockholder and financial blockholder indicate a blockholder with at least $25 \%$ of voting rights; Largest blockholder stake is the percentage of voting rights of the largest blockholder; Outsider ratio is the number of independent directors divided by the total number of directors, and a director is classified as independent only if he or she meets all criteria in the U.K. Combined Code on Corporate Governance; Adjusted outsider ratio is calculated as Outsider ratio, but treats all independent directors appointed by the current CEO as dependent directors; Firm-reported outsider ratio is the number of independent directors as reported by the firm divided by the total number of directors; Bankers on board ratio is the number of non-executive directors that are executives of bank over the total number of non-executive directors. External CEO turnover indicates turnover events where the outgoing CEO leaves the firm. Internal CEO turnover indicates a turnover event where the outgoing CEO stays in the firm. New CEO is outsider indicates whether (1) or not (0) a newly appointed CEO previously worked for the firm in any role. All accounting items are adjusted to US\$ in the year 2000. All continuous variables are winsorized at the 1st and 99th percentiles.

\begin{tabular}{|c|c|c|c|c|c|c|c|c|c|c|c|c|}
\hline \multirow[t]{2}{*}{ Sample } & \multicolumn{4}{|c|}{ Full } & \multicolumn{4}{|c|}{ U.K. } & \multicolumn{4}{|c|}{ Germany } \\
\hline & $N$ & Mean & Med. & SD & $N$ & Mean & Med. & SD & $N$ & Mean & Med. & SD \\
\hline \multicolumn{13}{|c|}{ Panel A: Firm characteristics } \\
\hline Market capitalization & 5,279 & 2.58 & 0.26 & 11.68 & 3,398 & 2.72 & 0.28 & 13.26 & 1,881 & 2.31 & 0.24 & 8.07 \\
\hline Assets & 5,279 & 9.29 & 0.37 & 54.97 & 3,398 & 7.23 & 0.32 & 48.26 & 1,881 & 13.01 & 0.56 & 65.21 \\
\hline Employees & 5,279 & 11.65 & 2.08 & 29.82 & 3,398 & 9.40 & 1.72 & 23.84 & 1,881 & 15.70 & 2.98 & 38.00 \\
\hline Leverage & 4,732 & 0.60 & 0.60 & 0.23 & 3,036 & 0.56 & 0.54 & 0.25 & 1,696 & 0.68 & 0.69 & 0.16 \\
\hline Return on assets $(R O A)$ & 5,279 & 0.13 & 0.12 & 0.13 & 3,398 & 0.13 & 0.13 & 0.15 & 1,881 & 0.12 & 0.12 & 0.09 \\
\hline Abnormal stock returns & 5,279 & -0.05 & -0.02 & 0.40 & 3,398 & -0.05 & -0.02 & 0.43 & 1,881 & -0.05 & -0.03 & 0.34 \\
\hline Financial firm & 5,279 & 0.10 & 0.00 & 0.30 & 3,398 & 0.11 & 0.00 & 0.31 & 1,881 & 0.10 & 0.00 & 0.30 \\
\hline Large blockholder exists & 5,279 & 0.46 & 0.00 & 0.50 & 3,398 & 0.25 & 0.00 & 0.44 & 1,881 & 0.82 & 1.00 & 0.39 \\
\hline ...that is a family & 4,743 & 0.14 & 0.00 & 0.35 & 2,883 & 0.06 & 0.00 & 0.23 & 1,860 & 0.27 & 0.00 & 0.45 \\
\hline ...that is a financial firm & 4,743 & 0.06 & 0.00 & 0.24 & 2,883 & 0.04 & 0.00 & 0.20 & 1,860 & 0.09 & 0.00 & 0.28 \\
\hline Largest blockholder stake & 4,770 & 30.59 & 17.39 & 28.17 & 2,910 & 14.81 & 12.00 & 11.07 & 1,860 & 55.29 & 52.07 & 29.06 \\
\hline \multicolumn{13}{|c|}{ Panel B: Board characteristics } \\
\hline Board size & 5,279 & 10.38 & 9.00 & 5.65 & 3,398 & 7.96 & 8.00 & 2.79 & 1,881 & 14.74 & 14.00 & 6.77 \\
\hline Executive directors & 5,279 & 3.87 & 4.00 & 1.81 & 3,398 & 3.89 & 4.00 & 1.73 & 1,881 & 3.83 & 3.00 & 1.93 \\
\hline Non-executive directors & 5,279 & 6.51 & 5.00 & 4.87 & 3,398 & 4.07 & 4.00 & 2.00 & 1,881 & 10.91 & 11.00 & 5.41 \\
\hline Outsider ratio, $\%$ & 2,890 & 0.43 & 0.43 & 0.16 & 2,890 & 0.43 & 0.43 & 0.16 & - & - & - & - \\
\hline Adjusted out. ratio, $\%$ & 2,890 & 0.19 & 0.14 & 0.20 & 2,890 & 0.19 & 0.14 & 0.20 & - & - & - & - \\
\hline Firm-reported. out. ratio, $\%$ & 3,398 & 0.49 & 0.50 & 0.15 & 3,398 & 0.49 & 0.50 & 0.15 & - & - & - & - \\
\hline Bankers on board ratio, $\%$ & 3,557 & 0.02 & 0.00 & 0.05 & 2,806 & 0.01 & 0.00 & 0.05 & 751 & 0.05 & 0.05 & 0.06 \\
\hline CEO age & 5,279 & 51.89 & 52.00 & 6.54 & 3,398 & 50.99 & 52.00 & 6.68 & 1,881 & 53.52 & 52.00 & 5.94 \\
\hline CEO age unknown & 5,279 & 0.14 & 0.00 & 0.35 & 3,398 & 0.03 & 0.00 & 0.18 & 1,881 & 0.35 & 0.00 & 0.48 \\
\hline CEO/chairman separated & 5,279 & 0.93 & 1.00 & 0.26 & 3,398 & 0.89 & 1.00 & 0.32 & 1,881 & 1.00 & 1.00 & 0.00 \\
\hline \multicolumn{13}{|c|}{ Panel C: CEO turnover characteristics } \\
\hline $\mathrm{P}$ (Total CEO turnover) & 5,279 & 0.15 & 0.00 & 0.36 & 3,398 & 0.16 & 0.00 & 0.36 & 1,881 & 0.15 & 0.00 & 0.36 \\
\hline $\mathrm{P}$ (External CEO turnover) & 5,279 & 0.11 & 0.00 & 0.32 & 3,398 & 0.11 & 0.00 & 0.32 & 1,881 & 0.11 & 0.00 & 0.31 \\
\hline $\begin{array}{l}\text { P(Internal CEO turnover) } \\
\mathrm{P}(\text { New CEO }\end{array}$ & 5,279 & 0.04 & 0.00 & 0.20 & 3,398 & 0.04 & 0.00 & 0.20 & 1,881 & 0.04 & 0.00 & 0.20 \\
\hline outsider|Turnov.) & 812 & 0.33 & 0.00 & 0.47 & 529 & 0.34 & 0.00 & 0.48 & 283 & 0.30 & 0.00 & 0.46 \\
\hline
\end{tabular}




\section{Table 2. Univariate Analysis of Sensitivity of Turnover to Past Performance}

This table reports CEO turnover frequencies in the U.K. and Germany, by performance quintiles. Performance quintiles are based on return on assets (ROA) in Panel A, industry-adjusted ROA (IAROA) in Panel $\mathrm{B}$, control-group adjusted ROA (CGAROA) in Panel $\mathrm{C}$ and abnormal stock returns $(A R)$ in Panel D. Quintile cutoff values are determined per country. ROA is EBITDA over lagged total assets. IAROA is ROA minus the two-digit SIC industry median ROA. If less than 3 firms are in the same two-digit SIC industry, the one-digit SIC industry level is

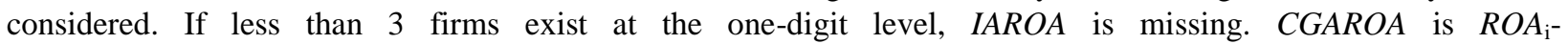
Median $\left(R O A_{\mathrm{k}} \mid \mathrm{k} \in \mathrm{G}_{\mathrm{i}}\right)$, where $\mathrm{G}_{\mathrm{i}}$ is the set of comparison firms for firm i. Comparison firms are in the same two-digit SIC industry as firm $\mathrm{i}$ and their performance in year $\mathrm{t}-1$ is within \pm 2 percentage points of $R O A_{\mathrm{i}}$. If no matching firm in the same industry is found, the control group is defined at the one-digit SIC industry level. If no matching firm is found at the one-digit level, CGAROA is missing. Control groups are calculated for each turnover observation and kept constant for the three year period surrounding the turnover event. Abnormal stock returns are risk-adjusted annual returns using a country-specific Fama French three factor model, where returns are dividend and stock split adjusted and factor loadings are estimated using monthly returns over the 24 month period preceding the fiscal year Results of t-tests of differences in turnover likelihood between the top and bottom performance quintiles are indicated by $*, * *, * * *$ and correspond to turnover likelihood differences being significantly different from 0 at the $10 \%, 5 \%$ and $1 \%$ confidence level.

\begin{tabular}{|c|c|c|c|c|c|c|c|c|c|c|}
\hline \multirow{2}{*}{$\begin{array}{l}\text { Sample } \\
\text { Quintile }\end{array}$} & \multicolumn{4}{|c|}{ U.K. } & & \multicolumn{5}{|c|}{ Germany } \\
\hline & $\begin{array}{c}\text { Q1 } \\
\text { lowest }\end{array}$ & Q2 & Q3 Q4 & $\begin{array}{c}\text { Q5 } \\
\text { highest }\end{array}$ & $\begin{array}{r}\text { t-test } \\
\text { Q1 vs. Q5 }\end{array}$ & $\begin{array}{c}\text { Q1 } \\
\text { lowest }\end{array}$ & Q2 & Q3 Q4 & $\begin{array}{c}\text { Q5 } \\
\text { highest Q }\end{array}$ & $\begin{array}{r}\text { t-test } \\
\text { vs. Q5 }\end{array}$ \\
\hline \multicolumn{11}{|c|}{ Panel A: Performance quintiles based on $R O A$} \\
\hline $\mathrm{P}$ (Total turnover) & $22 \%$ & $14 \%$ & $14 \% 15 \%$ & $12 \%$ & $* * *$ & $18 \%$ & $15 \%$ & $14 \% 17 \%$ & $12 \%$ & $* *$ \\
\hline (External turnover) & $17 \%$ & $11 \%$ & $10 \% 11 \%$ & $9 \%$ & $* * *$ & $14 \%$ & $12 \%$ & $9 \% 10 \%$ & $8 \%$ & $* * *$ \\
\hline $\mathrm{P}($ Internal t & $5 \%$ & $4 \%$ & $4 \% \quad 4 \%$ & $4 \%$ & & $4 \%$ & $2 \%$ & $5 \% \quad 7 \%$ & $4 \%$ & \\
\hline \multicolumn{11}{|c|}{ Panel B: Performance quintiles based on industry-adjusted ROA (IAROA) } \\
\hline $\begin{array}{l}\mathrm{P}(\text { Total turnover) } \\
\end{array}$ & $21 \%$ & $15 \%$ & $15 \% 14 \%$ & $13 \%$ & $* * *$ & $20 \%$ & $14 \%$ & $14 \% 15 \%$ & $12 \%$ & $* * *$ \\
\hline $\mathrm{P}($ External turnover $)$ & $16 \%$ & $11 \%$ & $11 \% 10 \%$ & $9 \%$ & $* * *$ & $16 \%$ & $10 \%$ & $9 \% 11 \%$ & $7 \%$ & $* * *$ \\
\hline urnover) & $5 \%$ & $3 \%$ & $4 \% \quad 4 \%$ & $4 \%$ & & $4 \%$ & $4 \%$ & $5 \% \quad 3 \%$ & $5 \%$ & \\
\hline \multicolumn{11}{|c|}{ Panel C: Performance quintiles based on control-group adjusted $R O A(C G A R O A)$} \\
\hline $\mathrm{P}$ (Total turnover) & $19 \%$ & $15 \%$ & $14 \% 11 \%$ & $16 \%$ & & $17 \%$ & $13 \%$ & $16 \% 10 \%$ & $12 \%$ & \\
\hline $\mathrm{P}($ External turnover $)$ & $14 \%$ & $11 \%$ & $10 \% \quad 8 \%$ & $11 \%$ & $*$ & $12 \%$ & $9 \%$ & $10 \% \quad 8 \%$ & $7 \%$ & $*$ \\
\hline $\mathrm{P}($ Internal turnover $)$ & $5 \%$ & $4 \%$ & $4 \% \quad 3 \%$ & $5 \%$ & & $4 \%$ & $4 \%$ & $6 \% \quad 3 \%$ & $5 \%$ & \\
\hline \multicolumn{11}{|c|}{ Panel D: Performance quintiles based on abnormal stock returns $(A R)$} \\
\hline$\overline{\mathrm{P}(\text { Total turnover })}$ & $21 \%$ & $16 \%$ & $14 \% 13 \%$ & $13 \%$ & $* * *$ & $22 \%$ & $12 \%$ & $12 \% 16 \%$ & $14 \%$ & $* * *$ \\
\hline $\mathrm{P}($ External turnover $)$ & $17 \%$ & $12 \%$ & $9 \% 10 \%$ & $9 \%$ & $* * *$ & $17 \%$ & $8 \%$ & $9 \% 10 \%$ & $10 \%$ & $* * *$ \\
\hline $\mathrm{P}($ Internal turnover) & $4 \%$ & $4 \%$ & $5 \% \quad 4 \%$ & $4 \%$ & & $5 \%$ & $4 \%$ & $3 \% \quad 6 \%$ & $4 \%$ & \\
\hline
\end{tabular}


Table 3. Multivariate Analysis of Sensitivity of Turnover to Past Performance

Probit regression results, the dependent variable is whether (1) or not (0) an external CEO turnover occurs in a firm year. All variables are as defined in Table 2. All regressions include year fixed effects. Standard errors are in brackets. *,** and $* * *$ indicate a coefficient significantly different from 0 at the $10 \%, 5 \%$ and $1 \%$ confidence level.

\begin{tabular}{|c|c|c|c|c|c|c|c|c|}
\hline & $(1)$ & (2) & (3) & (4) & $(5)$ & $(6)$ & (7) & $(8)$ \\
\hline$R O A_{\mathrm{t}-1}$ & $\begin{array}{c}-0.693 * * * * \\
{[0.199]}\end{array}$ & $\begin{array}{c}-0.754 * * * \\
{[0.180]}\end{array}$ & & & & & & \\
\hline$R O A_{\mathrm{t}-1} \mathrm{x}($ Germany $)$ & & $\begin{array}{c}0.235 \\
{[0.439]}\end{array}$ & & & & & & \\
\hline $\operatorname{IAROA}_{\mathrm{t}-1}$ & & & $\begin{array}{c}-0.670 * * * \\
{[0.188]}\end{array}$ & $\begin{array}{c}-0.740 * * * \\
{[0.187]}\end{array}$ & & & & \\
\hline$\left(I A R O A_{\mathrm{t}-1}\right) \mathrm{x}($ Germany $)$ & & & & $\begin{array}{c}0.355 \\
{[0.461]}\end{array}$ & & & & \\
\hline$C G A R O A_{\mathrm{t}-1}$ & & & & & $\begin{array}{c}-0.960 * * * \\
{[0.299]}\end{array}$ & $\begin{array}{c}-0.967 * * * \\
{[0.361]}\end{array}$ & & \\
\hline$\left(C G A R O A_{\mathrm{t}-1}\right) \mathrm{x}($ Germany $)$ & & & & & & $\begin{array}{c}0.068 \\
{[0.777]}\end{array}$ & & \\
\hline$A R_{\mathrm{t}-1}$ & & & & & & & $\begin{array}{c}-0.404 * * * \\
{[0.059]}\end{array}$ & $\begin{array}{c}-0.438 * * * * \\
{[0.069]}\end{array}$ \\
\hline$\left(A R_{\mathrm{t}-1}\right) \mathrm{x}($ Germany $)$ & & & & & & & & $\begin{array}{c}0.106 \\
{[0.137]}\end{array}$ \\
\hline Germany & & $\begin{array}{c}-0.238 * * * \\
{[0.080]}\end{array}$ & & $\begin{array}{c}-0.210 * * * \\
{[0.059]}\end{array}$ & & $\begin{array}{c}-0.281 * * * \\
{[0.074]}\end{array}$ & & $\begin{array}{c}-0.203 * * * \\
{[0.061]}\end{array}$ \\
\hline $\log \left(\operatorname{assets}_{\mathrm{t}-1}\right)$ & $\begin{array}{c}0.008 \\
{[0.014]}\end{array}$ & $\begin{array}{c}0.017 \\
{[0.013]}\end{array}$ & $\begin{array}{c}0.008 \\
{[0.014]}\end{array}$ & $\begin{array}{c}0.017 \\
{[0.013]}\end{array}$ & $\begin{array}{c}0.019 \\
{[0.018]}\end{array}$ & $\begin{array}{l}0.031 * \\
{[0.017]}\end{array}$ & $\begin{array}{c}0.013 \\
{[0.015]}\end{array}$ & $\begin{array}{c}0.022 \\
{[0.014]}\end{array}$ \\
\hline CEO age t $-1_{1}$ & $\begin{array}{c}0.018 * * * \\
{[0.004]}\end{array}$ & $\begin{array}{c}0.021 * * * \\
{[0.004]}\end{array}$ & $\begin{array}{c}0.018 * * * \\
{[0.004]}\end{array}$ & $\begin{array}{c}0.020 * * * \\
{[0.004]}\end{array}$ & $\begin{array}{c}0.021 * * * \\
{[0.004]}\end{array}$ & $\begin{array}{c}0.023 * * * \\
{[0.005]}\end{array}$ & $\begin{array}{c}0.017 * * * \\
{[0.003]}\end{array}$ & $\begin{array}{c}0.020 * * * \\
{[0.004]}\end{array}$ \\
\hline CEO age $_{t-1}$ unknown & $\begin{array}{c}0.325^{* * *} \\
{[0.068]}\end{array}$ & $\begin{array}{c}0.435^{* * * *} \\
{[0.068]}\end{array}$ & $\begin{array}{c}0.327 * * * \\
{[0.067]}\end{array}$ & $\begin{array}{c}0.435 * * * \\
{[0.068]}\end{array}$ & $\begin{array}{c}0.356 * * * \\
{[0.097]}\end{array}$ & $\begin{array}{c}0.501 * * * \\
{[0.089]}\end{array}$ & $\begin{array}{c}0.340 * * * \\
{[0.064]}\end{array}$ & $\begin{array}{c}0.453^{* * *} * \\
{[0.070]}\end{array}$ \\
\hline Financial firm & $\begin{array}{c}-0.301 * * * \\
{[0.109]}\end{array}$ & $\begin{array}{c}-0.324 * * * \\
{[0.090]}\end{array}$ & $\begin{array}{c}-0.271 * * \\
{[0.108]}\end{array}$ & $\begin{array}{c}-0.294 * * * \\
{[0.090]}\end{array}$ & $\begin{array}{c}-0.272 * * * \\
{[0.092]}\end{array}$ & $\begin{array}{c}-0.295 * * * \\
{[0.106]}\end{array}$ & $\begin{array}{c}-0.245^{* *} \\
{[0.099]}\end{array}$ & $\begin{array}{c}-0.265 * * * \\
{[0.091]}\end{array}$ \\
\hline $\begin{array}{l}\text { Year fixed effects } \\
\text { Observations }\end{array}$ & Yes & Yes & Yes & Yes & Yes & Yes & Yes & Yes \\
\hline Observations & 5,279 & 5,279 & 5,279 & 5,279 & 3,605 & 3,605 & 5,138 & 5,138 \\
\hline
\end{tabular}


Table 4. Univariate Analysis of the Effect of Turnover on Future Performance

This table reports changes in firm performance following CEO turnover, for both the following one-year and the following three-year period. Performance is reported for All quintiles, i.e. the full sample of CEO turnovers and for $Q L O W$, i.e. the subsample of CEO turnovers where firm performance is in the lowest performance quintile in the year prior to the CEO turnover event. Performance quintiles are based on ROA in Panel A, IAROA in Panel B, $C G A R O A$ in Panel C and $A R$ in Panel D. Performance measures are calculated as described in Table 2. Difference in medians between the full sample and the $Q L O W$ subsample are tested using the Wilcoxon rank sum test in Panels A to $\mathrm{C}$, and difference in means are tested using a t-test in Panel D.*, ** and $* * *$ indicate significant differences at the $10 \%, 5 \%$ and $1 \%$ confidence level.

\begin{tabular}{|c|c|c|c|c|c|c|c|c|c|}
\hline \multirow{2}{*}{$\begin{array}{l}\text { Sample } \\
\text { Performance } \\
\text { quintiles }\end{array}$} & \multicolumn{3}{|c|}{ Full } & \multicolumn{3}{|c|}{ U.K. } & \multicolumn{3}{|c|}{ Germany } \\
\hline & $\begin{array}{c}\text { All } \\
\text { quintiles }\end{array}$ & $\begin{array}{c}Q L O W \\
\text { only }\end{array}$ & $\begin{array}{r}\text { Diff All vs } \\
Q L O W\end{array}$ & $\begin{array}{c}\text { All } \\
\text { quintiles }\end{array}$ & $\begin{array}{c}Q L O W \\
\text { only }\end{array}$ & $\begin{array}{r}\text { Diff All vs } \\
Q L O W\end{array}$ & $\begin{array}{c}\text { All } \\
\text { quintiles }\end{array}$ & $\begin{array}{c}Q L O W \\
\text { only }\end{array}$ & $\begin{array}{r}\text { Diff All vs } \\
Q L O W\end{array}$ \\
\hline
\end{tabular}

Panel A: Performance based on ROA

\begin{tabular}{|c|c|c|c|c|c|c|c|c|c|}
\hline Period 0 to +1 & $0.3 \%$ & $3.6 \%$ & $* * *$ & $0.2 \%$ & $7.1 \%$ & $* * *$ & $0.4 \%$ & $2.7 \%$ & $*$ \\
\hline Period 0 to +3 & $2.2 \%$ & $11.0 \%$ & $* * *$ & $2.9 \%$ & $11.9 \%$ & $* *$ & $1.1 \%$ & $7.9 \%$ & $* * *$ \\
\hline \multicolumn{10}{|c|}{ Panel B: Performance based on industry-adjusted ROA (IAROA) } \\
\hline Period 0 to +1 & $-0.1 \%$ & $2.9 \%$ & $* * *$ & $-0.2 \%$ & $3.9 \%$ & $* * *$ & $0.0 \%$ & $2.3 \%$ & $*$ \\
\hline Period 0 to +3 & $0.3 \%$ & $6.8 \%$ & $* * *$ & $0.6 \%$ & $6.9 \%$ & $* *$ & $0.0 \%$ & $5.5 \%$ & $* * *$ \\
\hline
\end{tabular}

Panel C: Performance based on control-group adjusted ROA (CGAROA)

\begin{tabular}{|c|c|c|c|c|c|c|c|c|}
\hline Period 0 to +1 & $0.2 \%$ & $8.9 \%$ & $* * *$ & $0.1 \%$ & $9.4 \% * * *$ & $0.3 \%$ & $7.0 \%$ & $* * *$ \\
\hline Period 0 to +3 & $0.7 \%$ & $10.5 \%$ & $* * *$ & $0.9 \%$ & $12.2 \% * * *$ & $0.0 \%$ & $6.9 \%$ & $* *$ \\
\hline
\end{tabular}

\begin{tabular}{lllllllrll} 
Period 0 to +1 & $11.1 \%$ & $39.7 \%$ & $* * *$ & $14.5 \%$ & $50.4 \%$ & $* * *$ & $5.9 \%$ & $28.0 \%$ & $* * *$ \\
Period 0 to +3 & $14.3 \%$ & $48.3 \%$ & $* * *$ & $20.0 \%$ & $48.0 \%$ & $* * *$ & $10.5 \%$ & $50.2 \%$ & $* * *$ \\
\hline
\end{tabular}


Table 5. Dynamic Panel Data Regressions of Firm Performance

Blundell and Bond (1998) dynamic panel data regressions with fixed firm and year effects of the form

$$
y_{i t+1}=a_{0}+a_{1} y_{i t}+a_{2} y_{i t-1}+\beta^{\prime} x_{i t}+\gamma^{\prime} d_{t}+\eta_{i}+\varepsilon_{i t},
$$

where the dependent variable, $y i_{t+1}$, is future performance measured by ROA, IAROA, and CGAROA. In the estimation, year dummies $d_{t}$ are treated as strictly exogenous, whereas the regressors $x_{i t}$ are treated as predetermined. $Q L O W$ indicates whether (1) or not (0) a firm belongs to the bottom quintile of either industry adjusted $R O A$ or abnormal stock performance in year $t$ in columns (1)-(6). In all regressions, additional control variables include $\log$ (total assets), the log change in total assets, $\log$ (number of employees) and the log change of the number of employees. GMM standard errors are in brackets. *, ** and $* * *$ indicate a coefficient significantly different from 0 at the $10 \%, 5 \%$ and $1 \%$ confidence level.

\begin{tabular}{|c|c|c|c|c|c|c|}
\hline \multirow[t]{2}{*}{ Dependent variable: } & \multicolumn{2}{|c|}{$R O A_{\mathrm{t}+1}$} & \multicolumn{2}{|c|}{ IAROA $_{\mathrm{t}+1}$} & \multicolumn{2}{|c|}{ CGAROA $_{\mathrm{t}+1}$} \\
\hline & (1) & (2) & (3) & (4) & (5) & (6) \\
\hline \multirow[t]{2}{*}{ Turnover (yes/no) } & -0.002 & -0.004 & 0.001 & -0.001 & $-0.012 * *$ & $-0.024 * * *$ \\
\hline & {$[0.004]$} & {$[0.005]$} & {$[0.004]$} & {$[0.005]$} & {$[0.005]$} & {$[0.006]$} \\
\hline \multirow[t]{2}{*}{$Q L O W($ yes $/$ no $)$} & $-0.013 * * *$ & $-0.018 * * *$ & $-0.014 * * *$ & $-0.017 * * *$ & -0.004 & $-0.012 * *$ \\
\hline & [0.003] & {$[0.004]$} & [0.003] & {$[0.004]$} & [0.004] & {$[0.005]$} \\
\hline \multirow[t]{2}{*}{ (Turnover)x $(Q L O W)$} & $0.030 * * *$ & $0.036 * * *$ & $0.023 * * *$ & $0.030^{* * * *}$ & $0.033 * * *$ & $0.048 * * *$ \\
\hline & [0.007] & [0.008] & {$[0.007]$} & {$[0.008]$} & {$[0.011]$} & [0.013] \\
\hline \multirow[t]{2}{*}{ Germany } & & 0.007 & & 0.006 & & 0.008 \\
\hline & & {$[0.008]$} & & {$[0.008]$} & & [0.009] \\
\hline \multirow[t]{2}{*}{ (Turnover)x(Germany) } & & 0.005 & & 0.003 & & $0.043^{* * *}$ \\
\hline & & [0.009] & & [0.009] & & {$[0.011]$} \\
\hline \multirow[t]{2}{*}{$(Q L O W) \times($ Germany $)$} & & $0.013^{* *}$ & & 0.009 & & $0.020 * *$ \\
\hline & & {$[0.006]$} & & {$[0.006]$} & & [0.008] \\
\hline \multirow[t]{2}{*}{ (Turnover) $\mathrm{x}(Q L O W) \mathrm{x}($ Germany $)$} & & -0.019 & & -0.019 & & $-0.052 * *$ \\
\hline & & {$[0.014]$} & & [0.014] & & {$[0.023]$} \\
\hline \multirow{2}{*}{$R O A$} & $0.443 * * *$ & $0.438 * * *$ & & & & \\
\hline & {$[0.017]$} & {$[0.017]$} & & & & \\
\hline \multirow[t]{2}{*}{$R O A_{\mathrm{t}-1}$} & $0.024 * *$ & $0.025^{* *}$ & & & & \\
\hline & [0.011] & {$[0.011]$} & & & & \\
\hline \multirow[t]{2}{*}{ IAROA } & & & $0.401 * * *$ & $0.398 * * *$ & & \\
\hline & & & {$[0.018]$} & {$[0.017]$} & & \\
\hline \multirow[t]{2}{*}{$I_{A R O A_{\mathrm{t}-1}}$} & & & $0.036^{* * *}$ & $0.037 * * *$ & & \\
\hline & & & {$[0.011]$} & {$[0.011]$} & & \\
\hline \multirow[t]{2}{*}{ CGAROA } & & & & & $-0.153 * * *$ & $-0.151 * * *$ \\
\hline & & & & & {$[0.025]$} & {$[0.025]$} \\
\hline \multirow[t]{2}{*}{$C G A R O A_{\mathrm{t}-1}$} & & & & & $-0.141 * * *$ & $-0.138 * * *$ \\
\hline & & & & & {$[0.022]$} & [0.022] \\
\hline Control variables & Yes & Yes & Yes & Yes & Yes & Yes \\
\hline Year fixed effects & Yes & Yes & Yes & Yes & Yes & Yes \\
\hline Firm fixed effects & Yes & Yes & Yes & Yes & Yes & Yes \\
\hline Observations & 5,279 & 5,279 & 5,279 & 5,279 & 2,523 & 2,523 \\
\hline$\chi^{2}-$ statistic & 1239 & 1248 & 824.3 & 841.5 & 226.3 & 257.2 \\
\hline
\end{tabular}


Table 6. Corporate Restructuring Following CEO Turnover

Corporate restructuring following CEO turnover is reported as the median change in employees (Panel A) and the median change in assets (Panel B), for both the following one-year and the following three-year period. All quintiles includes the full sample of CEO turnovers, $Q L O W$ includes CEO turnovers where firm performance is in the lowest quintile in the fiscal year prior to the CEO turnover event. Performance quintiles are based on IAROA. ***,** and * indicate significance of Wilcoxon rank sum tests at the 1,5 and 10 percent level.

\begin{tabular}{|c|c|c|c|c|c|c|c|c|c|}
\hline \multirow{2}{*}{$\begin{array}{l}\text { Sample } \\
\text { Performance }\end{array}$} & \multicolumn{3}{|c|}{ Full } & \multicolumn{3}{|c|}{ U.K. } & \multicolumn{3}{|c|}{ Germany } \\
\hline & $\begin{array}{c}\text { All } \\
\text { quintiles }\end{array}$ & $\begin{array}{c}Q L O W \\
\text { only }\end{array}$ & $\begin{array}{l}\text { Diff All } \\
\text { vs } Q L O W\end{array}$ & $\begin{array}{c}\text { All } \\
\text { quintiles }\end{array}$ & $\begin{array}{c}Q L O W \\
\text { only }\end{array}$ & $\begin{array}{l}\text { Diff All } \\
\text { vs } Q L O W\end{array}$ & $\begin{array}{c}\text { All } \\
\text { quintiles }\end{array}$ & $\begin{array}{c}Q L O W \\
\text { only }\end{array}$ & $\begin{array}{l}\text { Diff All } \\
\text { vs } Q L O W\end{array}$ \\
\hline
\end{tabular}

\begin{tabular}{lrrrrrrrrr}
\hline Period 0 to +1 & $0.0 \%$ & $-5.1 \%$ & $* *$ & $0.4 \%$ & $-4.8 \%$ & $* *$ & $-0.7 \%$ & $-6.1 \%$ & \\
Period 0 to +3 & $-2.0 \%$ & $-15.1 \%$ & $* * *$ & $-0.4 \%$ & $-15.1 \%$ & $* *$ & $-4.3 \%$ & $-15.2 \%$ & $*$ \\
\hline \multicolumn{10}{c}{ Panel B: Percent change in assets } \\
\hline Period 0 to +1 & $-1.7 \%$ & $-7.9 \%$ & $* * *$ & $-0.4 \%$ & $-10.2 \%$ & $* *$ & $-2.6 \%$ & $-6.0 \%$ & $*$ \\
Period 0 to +3 & $-0.3 \%$ & $-11.8 \%$ & $* *$ & $-1.7 \%$ & $-5.8 \%$ & & $0.0 \%$ & $-20.6 \%$ & $*$ \\
\hline
\end{tabular}




\section{Table 7. Sensitivity of Turnover to Past Performance and Governance Mechanisms}

Probit regression results, the dependent variable is whether (1) or not (0) an external CEO turnover occurs in a firm year. Panels A and B include separate sets of governance variables and their interactions with performance. The governance variable is indicated at the top of each column. Each regression includes all firm-year observations for which the indicated governance variable is available. In Panel A, Board size is the sum of executive and nonexecutive directors in the U.K. and the number of supervisory board members in Germany. Outsider ${ }_{1}$ indicates whether (1) or not (0) the majority of board members are outside directors according to the U.K. Combined Code on Corporate Governance. Outsider ${ }_{2}$ is constructed as Outsider $_{1}$, but treats all independent directors appointed by the current CEO as dependent directors. Outsider $r_{3}$ is constructed as Outsider ${ }_{1}$, but classifies director independence as reported by the firm. Bankers on board is the number of directors that are executives of a bank (independent of whether that bank itself is included in the sample), divided by board size. CEO/Chair separated indicates that the role of CEO and Chairman is split between two individuals. In Panel B, Blockholder $\mathrm{M}_{\mathrm{M}}$, Family block $\mathrm{M}_{\mathrm{M}}$, and Institutional block $\mathrm{k}_{\mathrm{M}}$ indicate a blockholder with at least $25 \%$ of voting rights, constructed from manually collected data. Largest SH Perct ${ }_{\mathrm{M}}$ is the percentage of voting rights held by the largest shareholder, constructed from the same data. Blockholder $\mathrm{FL}_{\mathrm{F}}$ and Largest SH perct $\mathrm{FL}$ are the corresponding measures based on data that additionally incorporate Faccio and Lang (2002). All regressions include year fixed effects. Standard errors are in brackets. *, ** and $* * *$ indicate a coefficient significantly different from 0 at the $10 \%, 5 \%$ and $1 \%$ confidence level.

\begin{tabular}{|c|c|c|c|c|c|c|c|}
\hline \multicolumn{8}{|c|}{ Panel A: Board characteristics impact on the sensitivity of turnover to past performance } \\
\hline & $\begin{array}{c}\text { (1) } \\
\text { Board size }\end{array}$ & $\begin{array}{c}(2) \\
\log (\text { Board } \\
\text { size })\end{array}$ & $\begin{array}{c}\text { (3) } \\
\text { Outsider }_{1}\end{array}$ & $\begin{array}{c}\text { (4) } \\
\text { Outsider }_{2}\end{array}$ & $\begin{array}{c}\text { (5) } \\
\text { Outsider }_{3}\end{array}$ & $\begin{array}{c}\text { (6) } \\
\text { Bankers } \\
\text { on board }\end{array}$ & $\begin{array}{c}\text { (7) } \\
\text { CEO/Chair } \\
\text { separated }\end{array}$ \\
\hline $\operatorname{IAROA}_{\mathrm{t}-1}$ & $\begin{array}{c}-1.536^{* * *} \\
{[0.582]}\end{array}$ & $\begin{array}{c}-2.383 * * \\
{[1.107]}\end{array}$ & $\begin{array}{c}-1.271^{* *} \\
{[0.644]}\end{array}$ & $\begin{array}{c}-0.681 * * \\
{[0.280]}\end{array}$ & $\begin{array}{c}-0.677 \\
{[0.723]}\end{array}$ & $\begin{array}{c}-0.734 * * * * \\
{[0.188]}\end{array}$ & $\begin{array}{c}-1.160 * * \\
{[0.537]}\end{array}$ \\
\hline Germany & $\begin{array}{c}-0.629 * * * \\
{[0.143]}\end{array}$ & $\begin{array}{c}-1.244 * * * \\
{[0.295]}\end{array}$ & - & $\begin{array}{l}- \\
-\end{array}$ & $\begin{array}{l}- \\
-\end{array}$ & $\begin{array}{c}-0.254 * * * \\
{[0.064]}\end{array}$ & $\begin{array}{l}- \\
-\end{array}$ \\
\hline GOV Variable $t_{t-1}$ & $\begin{array}{c}-0.042 * * * \\
{[0.013]}\end{array}$ & $\begin{array}{c}-0.394 * * * \\
{[0.103]}\end{array}$ & $\begin{array}{c}0.852 * * * \\
{[0.202]}\end{array}$ & $\begin{array}{c}0.161 \\
{[0.167]}\end{array}$ & $\begin{array}{c}0.914 * * * \\
{[0.224]}\end{array}$ & $\begin{array}{c}-0.350 \\
{[0.223]}\end{array}$ & $\begin{array}{c}0.217 * * \\
{[0.099]}\end{array}$ \\
\hline$\left(G O V \operatorname{Var}_{t-1}\right) x(G e r)$ & $\begin{array}{c}0.046 * * * \\
{[0.013]}\end{array}$ & $\begin{array}{c}0.478 * * * \\
{[0.122]}\end{array}$ & $\begin{array}{l}- \\
-\end{array}$ & - & $\begin{array}{l}- \\
-\end{array}$ & $\begin{array}{c}0.495^{* *} \\
{[0.242]}\end{array}$ & - \\
\hline$\left(I A R O A_{\mathrm{t}-1}\right) \mathrm{x}(\mathrm{Ger})$ & $\begin{array}{c}1.240 \\
{[1.247]}\end{array}$ & $\begin{array}{l}3.606 \\
{[2.691]}\end{array}$ & - & - & - & $\begin{array}{c}0.336 \\
{[0.498]}\end{array}$ & - \\
\hline$\left(I A R O A_{\mathrm{t}-1}\right) \mathrm{x}\left(\mathrm{GOV} \operatorname{Var}_{\mathrm{t}-1}\right)$ & $\begin{array}{c}0.103 \\
{[0.073]}\end{array}$ & $\begin{array}{c}0.830 \\
{[0.558]}\end{array}$ & $\begin{array}{c}1.602 \\
{[1.332]}\end{array}$ & $\begin{array}{c}0.572 \\
{[0.926]}\end{array}$ & $\begin{array}{c}0.325 \\
{[1.402]}\end{array}$ & $\begin{array}{c}-0.081 \\
{[2.497]}\end{array}$ & $\begin{array}{c}0.468 \\
{[0.572]}\end{array}$ \\
\hline$\left(I_{A R O A_{\mathrm{t}-1}}\right) \mathrm{x}(\mathrm{Ger}) \mathrm{x}\left(\mathrm{GOV} \operatorname{Var}_{\mathrm{t}-1}\right)$ & $\begin{array}{c}-0.125 \\
{[0.104]}\end{array}$ & $\begin{array}{c}-1.549 \\
{[1.105]}\end{array}$ & $\begin{array}{l}- \\
-\end{array}$ & - & - & $\begin{array}{c}0.242 \\
{[2.747]}\end{array}$ & $\begin{array}{l}- \\
-\end{array}$ \\
\hline Control variables & Yes & Yes & Yes & Yes & Yes & Yes & Yes \\
\hline Year fixed effects & Yes & Yes & Yes & Yes & Yes & Yes & Yes \\
\hline Observations & 5,255 & 5,255 & 2,876 & 2,876 & 2,876 & 5,279 & 3,397 \\
\hline$\chi^{2}$ - statistic & 114.8 & 121.5 & 153.0 & 134.1 & 149.8 & 106.3 & 167.8 \\
\hline
\end{tabular}




\begin{tabular}{|c|c|c|c|c|c|c|}
\hline \multicolumn{7}{|c|}{ Panel B: Shareholder characteristics impact on the sensitivity of turnover to past performance } \\
\hline & $(1)$ & (2) & (3) & $(4)$ & (5) & (6) \\
\hline & $\begin{array}{l}\text { Block- } \\
\text { holder }_{M}\end{array}$ & $\begin{array}{l}\text { Block- } \\
\text { holder }_{F L}\end{array}$ & $\begin{array}{c}\text { Largest SH } \\
\text { Perct }_{M}\end{array}$ & $\begin{array}{l}\text { Largest SH } \\
\text { perct }_{\mathrm{FL}}\end{array}$ & $\begin{array}{l}\text { Family } \\
\text { block }_{M}\end{array}$ & $\begin{array}{l}\text { Institutional } \\
\text { block }_{\mathrm{M}}\end{array}$ \\
\hline \multirow[t]{2}{*}{ IAROA $A_{\mathrm{t}-1}$} & $-0.829 * * *$ & $-0.871 * * *$ & $-0.797 * *$ & $-1.149 * *$ & $-0.813 * * *$ & $-0.728 * * *$ \\
\hline & [0.236] & [0.295] & {$[0.334]$} & [0.476] & {$[0.231]$} & {$[0.223]$} \\
\hline \multirow[t]{2}{*}{ Germany } & $-0.348 * * *$ & $-0.193 * *$ & $-0.247 * *$ & 0.017 & -0.082 & $-0.115^{*}$ \\
\hline & {$[0.117]$} & {$[0.083]$} & {$[0.114]$} & {$[0.117]$} & {$[0.073]$} & [0.069] \\
\hline \multirow[t]{2}{*}{ GOV Variable $_{t-1}$} & 0.065 & 0.056 & 0.001 & $0.004 *$ & 0.000 & 0.048 \\
\hline & {$[0.072]$} & [0.089] & {$[0.003]$} & {$[0.002]$} & [0.149] & {$[0.178]$} \\
\hline \multirow[t]{2}{*}{$\left(G O V \operatorname{Var}_{t-1}\right) x(G e r)$} & 0.135 & 0.005 & 0.001 & $-0.006^{* *}$ & -0.142 & -0.190 \\
\hline & [0.133] & [0.124] & {$[0.003]$} & {$[0.003]$} & {$[0.176]$} & {$[0.240]$} \\
\hline \multirow[t]{2}{*}{$\left(I_{A R O A} A_{\mathrm{t}-1}\right) \mathrm{x}(\mathrm{Ger})$} & -1.207 & 0.205 & $-2.433 * *$ & -0.909 & 0.519 & 0.139 \\
\hline & [1.684] & [0.824] & {$[1.238]$} & [1.157] & {$[0.545]$} & {$[0.501]$} \\
\hline \multirow[t]{2}{*}{$\left(\right.$ IAROA $\left._{\mathrm{t}-1}\right) \mathrm{x}\left(\mathrm{GOV} \operatorname{Var}_{\mathrm{t}-1}\right)$} & 0.217 & 0.828 & 0.007 & 0.020 & 0.997 & -0.477 \\
\hline & [0.387] & {$[0.528]$} & {$[0.016]$} & {$[0.013]$} & [0.847] & [1.867] \\
\hline \multirow{2}{*}{$\left(I A R O A_{\mathrm{t}-1}\right) \times(\mathrm{Ger}) \mathrm{x}\left(\mathrm{GOV} \operatorname{Var}_{\mathrm{t}-1}\right)$} & 1.560 & -1.239 & 0.033 & -0.000 & $-2.453^{*}$ & -0.911 \\
\hline & [1.767] & [1.116] & {$[0.024]$} & {$[0.023]$} & [1.387] & [2.581] \\
\hline Control variables & Yes & Yes & Yes & Yes & Yes & Yes \\
\hline Year fixed effects & Yes & Yes & Yes & Yes & Yes & Yes \\
\hline Observations & 5,279 & 5,279 & 4,246 & 4,246 & 4,224 & 4,224 \\
\hline$\chi^{2}-$ statistic & 107.8 & 63.16 & 63.44 & 48.96 & 59.90 & 54.67 \\
\hline
\end{tabular}


Table 8. Post Turnover Performance and Governance Mechanisms

Blundell and Bond (1998) dynamic panel data regressions with fixed firm and year effects of the form

$$
y_{i t+1}=a_{0}+a_{1} y_{i t}+a_{2} y_{i t-1}+\beta^{\prime} x_{i t}+\gamma^{\prime} d_{t}+\eta_{i}+\varepsilon_{i t},
$$

where the dependent variable, $y_{i t+1}$, is future performance measured by industry-adjusted return on assets, IAROA. The corporate governance variable is indicated at the top of each column. Panel A reports results for board characteristics, and Panel B reports results for shareholder characteristics. All governance variables are described in Table 6. QLOW indicates whether (1) or not (0) a firm belongs to the bottom quintile of IAROA. In the estimation, year dummies $d_{t}$ are treated as strictly exogenous, whereas the regressors $x_{i t}$ are treated as predetermined. In all regressions, additional (unreported) control variables include $\log$ (total assets), the log change in total assets, $\log$ (number of employees) and the log change of the number of employees. GMM standard errors are in brackets. *, $* *$ and $* * *$ indicate a coefficient significantly different from 0 at the $10 \%, 5 \%$ and $1 \%$ confidence level.

\begin{tabular}{|c|c|c|c|c|c|c|c|}
\hline \multicolumn{8}{|c|}{ Panel A: Board characteristics in dynamic panel data regressions } \\
\hline & (1) & (2) & (3) & (4) & (5) & (6) & (7) \\
\hline & $\begin{array}{l}\text { Board } \\
\text { size }_{t-1}\end{array}$ & $\begin{array}{c}\log (\text { board } \\
\left.\text { size }_{t-1}\right)\end{array}$ & $\begin{array}{c}\text { Out- } \\
\text { sider }_{1, t-1}\end{array}$ & $\begin{array}{c}\text { Out- } \\
\text { sider }_{2, t-1}\end{array}$ & $\begin{array}{c}\text { Out- } \\
\text { sider }_{3, t-1}\end{array}$ & $\begin{array}{c}\text { Bankers on } \\
\text { board }_{t-1}\end{array}$ & $\begin{array}{l}\text { CEO/Chair } \\
\text { separated }_{t-1}\end{array}$ \\
\hline \multirow[t]{2}{*}{ IAROA } & $0.399 * * *$ & $0.399 * * *$ & $0.419 * * *$ & $0.414 * * *$ & $0.429 * * *$ & $0.408 * * *$ & $0.390 * * *$ \\
\hline & {$[0.017]$} & {$[0.017]$} & {$[0.023]$} & {$[0.023]$} & {$[0.024]$} & {$[0.021]$} & [0.017] \\
\hline \multirow{2}{*}{$I_{A R O A}$} & $0.037 * * *$ & $0.036 * * *$ & 0.013 & 0.010 & 0.016 & 0.017 & $0.037 * * *$ \\
\hline & {$[0.011]$} & {$[0.011]$} & {$[0.015]$} & {$[0.015]$} & {$[0.015]$} & {$[0.013]$} & {$[0.011]$} \\
\hline \multirow{2}{*}{ Turnover (yes/no) } & 0.001 & -0.007 & $-0.062 * * *$ & $-0.038 * *$ & -0.007 & -0.004 & -0.020 \\
\hline & [0.009] & [0.019] & {$[0.020]$} & {$[0.015]$} & [0.023] & [0.006] & [0.017] \\
\hline \multirow[t]{2}{*}{$Q L O W$ (yes/no) } & $-0.018 * * *$ & -0.019 & -0.020 & $-0.018 * * *$ & -0.005 & $-0.019 * * *$ & $-0.039 * * *$ \\
\hline & {$[0.006]$} & {$[0.013]$} & {$[0.012]$} & {$[0.006]$} & {$[0.015]$} & {$[0.004]$} & {$[0.010]$} \\
\hline \multirow[t]{2}{*}{ GOV Variable } & $-0.002 * *$ & $-0.021 * * *$ & $-0.039 *$ & $-0.061 * * *$ & 0.013 & -0.007 & 0.012 \\
\hline & {$[0.001]$} & {$[0.007]$} & {$[0.021]$} & {$[0.017]$} & {$[0.025]$} & {$[0.053]$} & {$[0.010]$} \\
\hline \multirow[t]{2}{*}{ (Turnover) $\mathrm{x}(Q L O W)$} & $0.037 * * *$ & $0.070^{* *}$ & $0.109 * * *$ & $0.064 * * *$ & $0.062 *$ & $0.034 * * *$ & $0.045^{*}$ \\
\hline & {$[0.013]$} & {$[0.029]$} & {$[0.029]$} & {$[0.022]$} & [0.034] & [0.009] & [0.025] \\
\hline \multirow{2}{*}{ (Turnover)x(GOV Var) } & -0.000 & 0.003 & $0.135^{* * *}$ & $0.120 * * *$ & 0.012 & 0.056 & 0.021 \\
\hline & [0.001] & [0.008] & {$[0.042]$} & {$[0.037]$} & {$[0.044]$} & [0.106] & [0.018] \\
\hline \multirow{2}{*}{$(Q L O W) \times(G O V$ Var $)$} & 0.000 & 0.003 & 0.010 & 0.026 & -0.020 & $0.109 *$ & $0.028 * * *$ \\
\hline & {$[0.000]$} & [0.006] & {$[0.025]$} & [0.021] & {$[0.029]$} & [0.061] & {$[0.010]$} \\
\hline \multirow[t]{2}{*}{ (Turnover) $\times(Q L O W) \times(\mathrm{GOV}$ Var) } & -0.002 & $-0.022^{*}$ & $-0.167 * * *$ & $-0.109 * *$ & -0.056 & -0.180 & -0.022 \\
\hline & [0.001] & {$[0.013]$} & {$[0.060]$} & {$[0.054]$} & {$[0.064]$} & {$[0.145]$} & {$[0.026]$} \\
\hline Contro & Yes & Yes & Yes & Yes & Yes & Yes & Yes \\
\hline Year fixed effects & Yes & $\mathrm{Ye}$ & $\mathrm{Ye}$ & Yes & Yes & Yes & Yes \\
\hline Firm fixed effects & Yes & Yes & Yes & Yes & Yes & Yes & Yes \\
\hline Observations & 5,279 & 5,279 & 2,890 & 2,890 & 2,890 & 3,557 & 5,279 \\
\hline$\chi^{2}-$ statistic & 847.4 & 856.8 & 541.1 & 524.6 & 529.9 & 589.0 & 837.1 \\
\hline
\end{tabular}




\begin{tabular}{|c|c|c|c|c|c|c|}
\hline \multicolumn{7}{|c|}{ Panel B: Shareholder characteristics in dynamic panel data regressions } \\
\hline & (1) & (2) & (3) & (4) & (5) & (6) \\
\hline & $\begin{array}{c}\text { Block- } \\
\text { holder }_{\mathrm{M}, \mathrm{t}-1}\end{array}$ & $\begin{array}{c}\text { Block- } \\
\text { holder }_{\text {FL,t-1 }}\end{array}$ & $\begin{array}{l}\text { Largest } \\
\text { perct }_{\mathrm{M}, \mathrm{t}-1}\end{array}$ & $\begin{array}{c}\text { Largest } \\
\text { perct }_{F L, t-1}\end{array}$ & $\begin{array}{c}\text { Family } \\
\text { block }_{\mathrm{M}, \mathrm{t}-1}\end{array}$ & $\begin{array}{c}\text { Institutional } \\
\text { block }_{\mathrm{M}, \mathrm{t}-1}\end{array}$ \\
\hline \multirow[t]{2}{*}{ IAROA } & $0.404 * * *$ & $0.407 * * *$ & $0.375^{* * *}$ & $0.422 * * *$ & $0.378 * * *$ & $0.380 * * *$ \\
\hline & {$[0.017]$} & {$[0.017]$} & {$[0.017]$} & {$[0.021]$} & {$[0.017]$} & {$[0.017]$} \\
\hline \multirow{2}{*}{$I A R O A_{\mathrm{t}-1}$} & $0.039 * * *$ & $0.041 * * *$ & $0.023 * *$ & $0.025^{*}$ & $0.020 *$ & $0.021 *$ \\
\hline & [0.011] & [0.011] & [0.011] & {$[0.014]$} & [0.011] & {$[0.011]$} \\
\hline \multirow[t]{2}{*}{ Turnover (yes/no) } & -0.006 & -0.005 & -0.004 & -0.006 & -0.002 & -0.001 \\
\hline & [0.006] & {$[0.006]$} & [0.006] & {$[0.008]$} & {$[0.005]$} & {$[0.004]$} \\
\hline \multirow[t]{2}{*}{$Q L O W($ yes/no $)$} & $-0.016 * * *$ & $-0.017 * * *$ & $-0.017 * * *$ & $-0.012 * *$ & $-0.015^{* * *}$ & $-0.014 * * *$ \\
\hline & {$[0.004]$} & {$[0.004]$} & {$[0.004]$} & {$[0.005]$} & {$[0.003]$} & {$[0.003]$} \\
\hline \multirow[t]{2}{*}{ GOV Variable } & $-0.010 * *$ & $-0.012 * *$ & $0.000^{*}$ & 0.000 & $0.026 * * *$ & $-0.019 *$ \\
\hline & {$[0.004]$} & {$[0.004]$} & {$[0.000]$} & {$[0.000]$} & {$[0.009]$} & [0.011] \\
\hline \multirow[t]{2}{*}{ (Turnover) $\mathrm{x}(Q L O W)$} & $0.031 * * *$ & $0.037 * * *$ & $0.032 * * *$ & $0.029 * *$ & $0.022 * * *$ & $0.025^{* * *}$ \\
\hline & [0.009] & {$[0.009]$} & {$[0.010]$} & {$[0.013]$} & {$[0.007]$} & [0.007] \\
\hline \multirow[t]{2}{*}{ (Turnover)x(GOV Var) } & 0.013 & 0.011 & 0.000 & 0.000 & -0.008 & -0.010 \\
\hline & {$[0.008]$} & {$[0.008]$} & {$[0.000]$} & {$[0.000]$} & {$[0.012]$} & {$[0.017]$} \\
\hline \multirow[t]{2}{*}{$(Q L O W) \times(G O V$ Var $)$} & 0.004 & 0.004 & 0.000 & 0.000 & 0.005 & -0.019 \\
\hline & {$[0.005]$} & {$[0.005]$} & {$[0.000]$} & {$[0.000]$} & {$[0.008]$} & {$[0.012]$} \\
\hline \multirow{2}{*}{ (Turnover)x $(Q L O W) \times G O V$ Var) } & -0.016 & $-0.029 * *$ & -0.000 & -0.000 & 0.018 & -0.033 \\
\hline & {$[0.013]$} & {$[0.013]$} & {$[0.000]$} & {$[0.000]$} & [0.020] & {$[0.028]$} \\
\hline Control variables & Yes & Yes & Yes & Yes & Yes & Yes \\
\hline Year fixed effects & Yes & Yes & Yes & Yes & Yes & Yes \\
\hline Firm fixed effects & Yes & Yes & Yes & Yes & Yes & Yes \\
\hline Observations & 5,279 & 5,279 & 4,770 & 4,770 & 4,743 & 4,743 \\
\hline$\chi^{2}-$ statistic & 917.1 & 906.1 & 811.5 & 637.4 & 836.9 & 841.7 \\
\hline
\end{tabular}


Table 9. Post Turnover Performance and Governance Mechanisms By Country

Blundell and Bond (1998) dynamic panel data regressions with fixed firm and year effects of the form

$$
y_{i t+1}=a_{0}+a_{1} y_{i t}+a_{2} y_{i t-1}+\beta^{\prime} x_{i t}+\gamma^{\prime} d_{t}+\eta_{i}+\varepsilon_{i t},
$$

where the dependent variable, $y_{i t+1}$, is future performance measured by industry-adjusted return on assets, IAROA. The corporate governance variable is indicated at the top of each column. Regressions are identical to those in Table 7, except that the full sample is split into subsamples of firms incorporated in the U.K. and Germany, respectively. The table reports coefficients and standard errors (in brackets) of the triple interaction (Turnover) $\mathrm{x}(\mathrm{QLOW}) \mathrm{x}(\mathrm{GOV}$ Var).

\begin{tabular}{|c|c|c|c|c|c|c|c|}
\hline & \multicolumn{7}{|c|}{ Panel A: Board characteristics in dynamic panel data regressions } \\
\hline & (1) & (2) & (3) & (4) & (5) & (6) & (7) \\
\hline Sample & Board size $_{\mathrm{t}-1}$ & $\begin{array}{c}\log (\text { board } \\
\left.\text { size }_{t-1}\right)\end{array}$ & Outsider $_{1, t-1}$ & Outsider $_{2}, t-1$ & Outsider $_{3, t-1}$ & $\begin{array}{c}\text { Bankers on } \\
\text { board }_{t-1}\end{array}$ & $\begin{array}{l}\text { CEO/Chair } \\
\text { separated }_{\mathrm{t}-1}\end{array}$ \\
\hline U.K. & $\begin{array}{c}-0.003 \\
{[0.003]}\end{array}$ & $\begin{array}{c}-0.029 \\
{[0.025]}\end{array}$ & $\begin{array}{c}-0.167 * * * \\
{[0.060]}\end{array}$ & $\begin{array}{c}-0.109 * * \\
{[0.054]}\end{array}$ & $\begin{array}{c}-0.056 \\
{[0.064]}\end{array}$ & $\begin{array}{c}-0.023 \\
{[0.247]}\end{array}$ & $\begin{array}{c}-0.017 \\
{[0.029]}\end{array}$ \\
\hline Germany & $\begin{array}{c}0.000 \\
{[0.001]}\end{array}$ & $\begin{array}{c}0.003 \\
{[0.017]}\end{array}$ & - & - & - & $\begin{array}{c}0.161 \\
{[0.233]}\end{array}$ & - \\
\hline \multicolumn{8}{|c|}{ Panel B: Shareholder characteristics in dynamic panel data regressions } \\
\hline & $\begin{array}{c}(8) \\
\text { Block-holder }_{\text {Mt- }}\end{array}$ & $\begin{array}{c}(9) \\
\text { Block- } \\
\text { holder }\end{array}$ & $\begin{array}{c}(10) \\
\text { Largest } \\
\text { perct }_{\mathrm{Mt}-1}\end{array}$ & $\begin{array}{c}(11) \\
\text { Largest } \\
\text { perct }\end{array}$ & $\begin{array}{c}(12) \\
\text { Family } \\
\text { block }_{\mathrm{Mt}-1}\end{array}$ & $\begin{array}{c}(13) \\
\text { Institutional } \\
\text { block }_{\mathrm{Mt}-1}\end{array}$ & \\
\hline U.K. & $\begin{array}{c}-0.018 \\
{[0.021]}\end{array}$ & $\begin{array}{l}-0.040^{*} \\
{[0.024]}\end{array}$ & $\begin{array}{l}-0.001 \\
{[0.001]}\end{array}$ & $\begin{array}{c}-0.001 \\
{[0.001]}\end{array}$ & $\begin{array}{c}-0.003 \\
{[0.029]}\end{array}$ & $\begin{array}{c}-0.066 \\
{[0.046]}\end{array}$ & \\
\hline Germany & $\begin{array}{c}0.006 \\
{[0.022]}\end{array}$ & $\begin{array}{c}0.010 \\
{[0.024]}\end{array}$ & $\begin{array}{c}0.000 \\
{[0.000]}\end{array}$ & $\begin{array}{c}0.001 \\
{[0.000]}\end{array}$ & $\begin{array}{c}-0.021 \\
{[0.017]}\end{array}$ & $\begin{array}{c}0.038 \\
{[0.030]}\end{array}$ & \\
\hline
\end{tabular}

